\title{
New Highly Charged Iron(III) Metal-Organic Cube Stabilized by a Bulky Amine
}

\author{
Carlos Cruz, Andrés Igor Vega Carvallo, Evgenia Spodine, Albert Escuer, José F. Marco, \\ Nieves Menéndez, Diego Venegas-Yazigi, and Verónica Paredes-García*
}

Cite This: ACS Omega 2020, 5, 22238-22247

Read Online

\section{ACCESS}

џll Metrics \& More

Article Recommendations

Supporting Information

ABSTRACT: In this work, we report a new octanuclear cluster based on $\mathrm{Fe}^{\mathrm{III}}$ and the ligand $1 \mathrm{H}$-imidazole-4,5-dicarboxylic acid, $\left[\mathrm{Et}_{3} \mathrm{NH}\right]_{12}\left[\mathrm{Fe}_{8}(\mathrm{IDC})_{12}\right] \cdot 10 \mathrm{DMF} \cdot 13 \mathrm{H}_{2} \mathrm{O}(\mathbf{1})$, with a metal core containing eight $\mathrm{Fe}^{\mathrm{III}}$ connected by only one type of organic ligand. A peak at $573 \mathrm{~m} / z$ in the mass spectra of the compound suggests the adduct species $\left\{\left[\mathrm{Fe}_{8}(\mathrm{IDC})_{12}\right]+8 \mathrm{H}\right\}^{4-}$. By Xray photoelectron spectroscopy, the oxidation state of the iron cation was confirmed to be $3+$, also identifying the presence of a quaternary nitrogen species, which act as a countercation of the anionic metal core $\left[\mathrm{Fe}_{8}(\mathrm{IDC})_{12}\right]^{12-}$. Mössbauer spectra recorded at different temperatures show an isomer shift and quadrupole splitting parameters that confirm the existence of only $\mathrm{Fe}^{\mathrm{III}}$-HS in the structure of $\mathbf{1}$. X-ray analysis reveals that compound $\mathbf{1}$ crystallizes in the orthorhombic system space group Ibam, confirming a molecular cluster structure with an almost regular cube as geometry, with the $\mathrm{Fe}^{\mathrm{III}}$ atoms located at the corners of the cube and connected by $\mu-1 \kappa^{2} N, O: 2 \kappa^{2} N^{\prime}, O^{\prime \prime \prime}$-IDC ${ }^{3-}$ bridges. Additionally, the magnetic measurements reveal a weak antiferromagnetic coupling in the $\mathrm{Fe}_{8}{ }^{\mathrm{III}}$ coordination cluster $\left(J=-3.8 \mathrm{~cm}^{-1}\right)$. To the best of our knowledge, $\mathbf{1}$ is the first member of the family of cubes assembled with $1 \mathrm{H}$ imidazole-4,5-dicarboxylic acid and $\mathrm{Fe}^{\mathrm{III}}$ cation, exhibiting high $\mathrm{pH}$ stability over a broad $\mathrm{pH}$ range, making it an ideal candidate for the design of supramolecular structures and metal-organic frameworks.

\section{INTRODUCTION}

One of the fascinating fields in coordination chemistry is the research in polynuclear molecular compounds, also called coordination clusters. This type of compound corresponds to molecular entities formed by multiple metal cation arrangements, connected by organic or inorganic ligands. ${ }^{1}$ The molecular structure and properties of the coordination cluster are intrinsically related to the nature of the chosen metal center and the interaction between them through the bridging ligands. ${ }^{2-4}$ Then, coordination clusters presenting cations with unpaired electrons are attractive in the field of molecular magnetism. $^{5-8}$ The slow relaxation of the magnetization reported for the disc-shaped $\mathrm{Mn}_{12}{ }^{\mathrm{II} / \mathrm{III}}$ compound, $\left[\mathrm{Mn}_{12} \mathrm{O}_{12}\left(\mathrm{O}_{2} \mathrm{CR}\right)_{16}\left(\mathrm{H}_{2} \mathrm{O}\right)_{4}\right](\mathrm{R}=$ methyl, phenyl), is a product of the high-spin state and magnetic anisotropy of the paramagnetic centers. ${ }^{9,10}$ Furthermore, two $\mathrm{Cr}_{10}$ III wheels bridged by acetate and alkoxide ligands, $\left[\mathrm{Cr}_{10}\left(\mathrm{O}_{2} \mathrm{CMe}\right)_{10}(\mathrm{OR})_{20}\right]$, show a different magnetic behavior depending on the alkoxide ligand present in the wheel. The authors report that the methoxide ligand favors a ferromagnetic behavior, while the ethoxide ligand favors an antiferromagnetic behavior. ${ }^{11}$ Additionally, two mixed-valence coordination clusters $\left[\mathrm{Mn}_{12}{ }^{\mathrm{III}} \mathrm{Mn}_{7}{ }^{\mathrm{II}} \mathrm{O}_{8}(\mathrm{HL})_{12}\left(\mathrm{~N}_{3}\right)_{3}(\mathrm{MeO})_{5.5}(\mathrm{MeOH})_{3.5}\right.$ $\left.\left(\mathrm{H}_{2} \mathrm{O}\right)_{1.5}(\mathrm{OH})_{0.5}\right](\mathrm{OAc}) \cdot 10 \mathrm{H}_{2} \mathrm{O}$ and $\left[\mathrm{Na}_{2} \mathrm{Mn}_{11}{ }_{\mathrm{III}}\right.$ $\left.\mathrm{Mn}_{4}{ }^{\mathrm{II}} \mathrm{O}_{8}(\mathrm{HL})_{10}(\mathrm{OAc})_{2}\left(\mathrm{H}_{2} \mathrm{O}\right)_{2}\left(\mathrm{OCH}_{3}\right)_{1.5}\left(\mathrm{~N}_{3}\right)_{2.5}\right](\mathrm{OAc})$. $10 \mathrm{H}_{2} \mathrm{O} \cdot 2 \mathrm{MeOH}\left(\mathrm{H}_{3} \mathrm{~L}=2,6\right.$-(hydroxymethyl)phenol), reported in the literature exhibit the magnetocaloric effect at low temperatures due to the large spin, small anisotropy, and high density of low-lying excited states. ${ }^{12}$ Research in coordination clusters based on $\mathrm{Fe}^{\mathrm{III}}$ is interesting in molecular magnetism not only by its rich coordination chemistry but also because this spin carrier can present spin values ranging from $5 / 2$ to $1 / 2$, depending on the coordination environment. These features make these types of compounds attractive for applications like spin switches and magnetic refrigerants. ${ }^{13-16}$

From a structural viewpoint, the literature reports several $\mathrm{Fe}^{\mathrm{III}}$ coordination clusters with a wide variety of nuclearities, topologies, and geometries, such as $\left[\mathrm{Fe}_{6}\left(\mathrm{O}_{2}\right) \mathrm{O}_{2}\right.$ $\left.\left(\mathrm{O}_{2} \mathrm{CPh}\right)_{12}\left(\mathrm{H}_{2} \mathrm{O}\right)_{2}\right]$ reported by McCusker et al. ${ }^{17}$ and $\left\{\left[\mathrm{Fe}_{8}(\mathrm{O})_{2}(\mathrm{OH})_{12}(\mathrm{tacn})_{6}\right] \mathrm{Br}_{7}\left(\mathrm{H}_{2} \mathrm{O}\right)\right\} \mathrm{Br} \cdot 8 \mathrm{H}_{2} \mathrm{O}$ reported by Wieghardt et al. ${ }^{18}\left(\mathrm{O}_{2} \mathrm{CPh}^{-}=\right.$benzoate; tacn $=1,4,7$ triazacyclononane). Both compounds present planar moieties as central cores, constructed by oxides/peroxides anions in the case of $\mathrm{Fe}_{6}$ and oxides/hydroxides anions in $\mathrm{Fe}_{8}$. Using phosphonic acids, Konar et al. obtained $\left[\mathrm{Fe}_{9}\left(\mu_{3}-\mathrm{O}\right)_{4}\left(\mathrm{O}_{3} \mathrm{PPh}-\right.\right.$

Received: May 22, 2020

Accepted: July 7, 2020

Published: August 14, 2020 
$\left.\left.(\mathrm{Me})_{2}\right)_{3}\left(\mathrm{O}_{2} \mathrm{CCMe}_{3}\right)_{13}\right]$ and $\left[\mathrm{Fe}_{12}\left(\mu_{2}-\mathrm{O}\right)_{4}\left(\mu_{3}-\right.\right.$ $\left.\mathrm{O})_{4}\left(\mathrm{O}_{2} \mathrm{CCHPh}\right)_{14}\left(4-\mathrm{buPhPO}_{3} \mathrm{H}\right)_{6}\right]\left(\mathrm{O}_{3} \mathrm{PPh}(\mathrm{Me})_{2}{ }^{2-}=3,5-\right.$ dimethylphenyl phosphonate; $\mathrm{O}_{2} \mathrm{CCMe}_{3}{ }^{-}=$pivalate; $\mathrm{O}_{2} \mathrm{CCHPh}_{2}{ }^{-}=$diphenylacetate; $4{ }^{t}{ }^{\mathrm{buPhPO}} \mathrm{Ph}_{3} \mathrm{H}^{-}=$ p-butylphenyl phosphonate), with $\mathrm{Fe}_{9}$ and $\mathrm{Fe}_{12}$ central cores, showing an icosahedral and a double butterfly structure, respectively. ${ }^{19}$ Kang et al. reported the mixed-valence $\mathrm{Fe}_{18}{ }^{\text {III }} \mathrm{Fe}_{24}$ II coordination cluster $\left[\left\{\mathrm{Fe}(\mathrm{Tp})(\mathrm{CN})_{3}\right\}_{24}\{\mathrm{Fe}-\right.$ $\left.\left.\left(\mathrm{H}_{2} \mathrm{O}\right)_{2}\right\}_{6}\left\{\mathrm{Fe}(\mathrm{dpp})\left(\mathrm{H}_{2} \mathrm{O}\right)\right\}_{12}\left(\mathrm{CF}_{3} \mathrm{SO}_{3}\right)_{6}\right] \cdot 18 \mathrm{H}_{2} \mathrm{O}(\mathrm{Tp}=$ hydrotris(pyrazolyl)borate; dpp $=1,3-\mathrm{di}$ (4-pyridyl)propane). ${ }^{20}$ The $\mathrm{Fe}_{18}{ }_{18}^{\mathrm{III}} \mathrm{Fe}_{24}{ }^{\mathrm{II}}$ cluster has a number large enough of metal centers to be considered as a nanocage. ${ }^{20}$

From the experimental viewpoint, several polynuclear $\mathrm{Fe}^{\mathrm{III}}$ compounds found in the literature were synthesized using two or more ligands, giving rise in many cases to complex structures. ${ }^{21-23}$ In this article, we report a novel $\mathrm{Fe}_{8}{ }^{\mathrm{III}}$ octanuclear cube-type coordination cluster $\left[\mathrm{Et}_{3} \mathrm{NH}\right]_{12}\left[\mathrm{Fe}_{8}(\mathrm{IDC})_{12}\right] \cdot 10 \mathrm{DMF} \cdot 13 \mathrm{H}_{2} \mathrm{O}$ (1) obtained using $1 \mathrm{H}$-imidazole-4,5-dicarboxylic acid ( $\left.\mathrm{H}_{3} \mathrm{IDC}\right)$ as a unique ligand. The structure and composition of the octanuclear cluster were obtained by single-crystal X-ray diffraction, X-ray photoelectron spectroscopy (XPS), and other complementary techniques. Furthermore, the characterization of $\mathbf{1}$ was complemented with Mössbauer spectroscopy, electronic paramagnetic resonance, and magnetic susceptibility measurements.

\section{EXPERIMENTAL SECTION}

2.1. Synthesis of $\left[\mathrm{Et}_{3} \mathrm{NH}\right]_{12}\left[\mathrm{Fe}_{8}(\mathrm{IDC})_{12}\right] \cdot 10 \mathrm{DMF} \cdot 13 \mathrm{H}_{2} \mathrm{O}$ (1). Caution: The reaction involves the mixture of a moderate amount of triethylamine $\left(\mathrm{Et}_{3} \mathrm{~N}\right)$ and glacial acetic acid $\left(\mathrm{CH}_{3} \mathrm{COOH}\right)$. Fuming vapors are released, so care must be taken in this procedure.

To a suspension of $\mathrm{Fe}(\mathrm{acac})_{3}(0.5 \mathrm{mmol})$ and $\mathrm{H}_{3} \mathrm{IDC}$ (1 $\mathrm{mmol}$ ) in a mixture of $10 \mathrm{~mL}$ of water and $N, N^{\prime}$ dimethylformamide (DMF) (1:1 $\left.\mathrm{H}_{2} \mathrm{O} / \mathrm{DMF}\right), 5 \mathrm{~mL}$ of $\mathrm{Et}_{3} \mathrm{~N}$ was added with constant stirring. After a few minutes, the suspension disappears, and the resulting dissolution changes the initial orange color to a deep red color. After $10 \mathrm{~min}$ of stirring, 5 $\mathrm{mL}$ of glacial $\mathrm{CH}_{3} \mathrm{COOH}$ was added, giving a deep reddishbrown solution, which was left undisturbed for a few weeks, giving yellow prismatic crystals of 1 (Figure S1). MW $=4475.86$ g/mol. Yield: $50 \%$ based on iron(III) salt. Anal. Calc. for: $\mathrm{C}_{162} \mathrm{H}_{300} \mathrm{~N}_{46} \mathrm{O}_{71} \mathrm{Fe}_{8}$ (1): C, 43.47\%; H, 6.77\%; N, 14.40\%; Fe, 9.98\%. Found: C, 43.35\%; H, 6.71\%; N, 14.36\%; Fe, 9.98\%.

2.2. Physical Measurements. 2.2.1. Elemental Analysis. The quantitative content of $\mathrm{C}, \mathrm{H}$, and $\mathrm{N}$ was obtained on a Thermos CHNS flash 2000 elemental analyzer using solid crystalline samples of $\mathbf{1}$. The quantitative content of Fe was determined using atomic absorption spectroscopy. Three samples of $\mathbf{1}$ from different batches were measured in triplicate. Solid crystalline samples of 1 were digested in a $0.5 \% \mathrm{HNO}_{3}$ solution, and the iron concentration was measured with a Perkin Elmer PinAAcle 900F atomic absorption spectrophotometer equipped with an acetylene burner using a flux of acetylene:air of 2.51:10 $\mathrm{L} \mathrm{min}^{-1}$ as an oxidant mixture. An Fe lamp of $248.33 \mathrm{~nm}$ wavelength was used with standard solutions in a linear range of $0.1-3,0 \mathrm{mg}_{\mathrm{Fe}} \mathrm{L}^{-1}$.

2.2.2. Mass Spectrometry. Mass spectra were measured in a Linear Ion Trap LTQ-XL Thermo Scientific spectrometer and were analyzed with the software MMass 5.5.0. ${ }^{24-26}$ The analysis was carried out in a DMF: $\mathrm{H}_{2} \mathrm{O}$ solution of $1(\mathrm{pH} \approx 6.0)$ in negative ion mode, scanning in a range of $\mathrm{m} / z$ of $150-1500$ (Table S2 shows the peak list of the mass spectrum).
2.2.3. Thermogravimetric Analysis. Thermogravimetric (TG) analysis was performed on a Mettler Toledo TGA/DSC STAR system. The samples were introduced in an alumina holder and heated under a nitrogen atmosphere from room temperature to $900{ }^{\circ} \mathrm{C}$ at a heating rate of $5{ }^{\circ} \mathrm{C} / \mathrm{min}$.

2.2.4. Single-Crystal $X$-ray Diffraction. A single crystal of 1 was directly selected from the reaction beaker and glued on the tip of a capillary glass using epoxy resin. Scans on the Bruker APEXII diffractometer confirmed enough crystal quality to perform full recording using X-ray radiation of Mo $\mathrm{K} \alpha(\lambda=$ $0.71073 \AA)$. The data were reduced by SAINT, ${ }^{27}$ and empirical absorption corrections were applied using SADABS. ${ }^{28}$ The structure was solved with the ShelXT ${ }^{29}$ structure solution program using direct methods and refined with the ShelXL ${ }^{30}$ refinement package with least-squares minimization. Additional data concerning the crystallographic and the refinement parameters are detailed in the Supporting Information. ToposPro 5.0 software ${ }^{31}$ was used for structure drawing. During the structure completion process by difference Fourier synthesis, it was clear that there was a high amount of space left by the $\mathrm{Fe}_{8}$ cubes of the complex within the cell, having an ill-defined electron density. Although the triethylammonium and water molecules were identified preliminarily at this point, refinement by any model we tried was unsuccessful. Efforts to measure at low temperatures failed since crystals crack. Synthetic modifications were also tried to change triethylammonium by an alkaline metal or other ammonium such as tetramethylammonium or tetraethylammonium without any good results. Since efforts to model the disorder of the solvating molecules by using a meaningful scheme failed, a well-documented method for the modeling of unresolved electron density, PLATONSQUEEZE, was used. ${ }^{32,33}$ Alert B is present in the check cif file. CHEMS01 Type_1 is due to the use of the " $\left[\mathrm{Fe}_{8} \mathrm{C}_{60} \mathrm{H}_{12} \mathrm{~N}_{24} \mathrm{O}_{48}\right.$ + solvent]" expression to remark that the reported formula $\mathrm{Fe}_{8} \mathrm{C}_{60} \mathrm{H}_{12} \mathrm{~N}_{24} \mathrm{O}_{48}$ lacks a specific amount of solvent and countercations molecules because of the use of SQUEEZE. PLAT084 and PLAT230 can be assigned to the unresolved effects such as the disorder in chemical species. Despite this, most of the structural determination alerts are related to cation/ solvent disorder, thus allowing one to consider that the geometry for the $\mathrm{Fe}_{8}$ cluster is reliable. Therefore, based on the complementary analyses, 12 triethylammonium $\left(\mathrm{Et}_{3} \mathrm{NH}^{+}\right)$ as counterions, $10 \mathrm{~N}, \mathrm{~N}^{\prime}$-dimethylformamide, and 13 water crystallization molecules per $\mathrm{Fe}_{8}$ cube unit were included in the final formula $\left(\mathrm{C}_{162} \mathrm{H}_{300} \mathrm{~N}_{46} \mathrm{O}_{71} \mathrm{Fe}_{8}\right)$.

2.2.5. X-ray Photoelectron Spectroscopy. XPS data were recorded using a PHOIBOS-150 hemispherical electron analyzer (Specs) under a pressure lower than $2 \times 10^{-9} \mathrm{mbar}$ using $\mathrm{Al} \mathrm{K} \alpha$ radiation. The $\mathrm{X}$-ray gun was operated at a power of $100 \mathrm{~W}$ to minimize radiation-induced damage to the sample. All the spectra were recorded at a constant pass energy of $30 \mathrm{eV}$. The binding energy scale was referenced to the main $\mathrm{C}$ 1s contribution due to aliphatic carbon, which was set at $284.6 \mathrm{eV}$. All spectra were computer-fitted to a sum of pseudo-Voigt profiles using Shirley background subtraction.

2.2.6. Mössbauer Spectroscopy. The Mössbauer spectra of finely ground crystals of 1 were recorded between 295 and $4.2 \mathrm{~K}$. The measurements were recorded using two ${ }^{57} \mathrm{Co}(\mathrm{Rh}) \gamma$-ray sources mounted on both ends of an electromagnetic transducer operated in the triangular mode. One of the sources was used for energy calibration with $\alpha$-Fe $(6 \mu \mathrm{m})$ foil. The spectra were analyzed by a nonlinear fit using the NORMOS program, ${ }^{34}$ and the energy calibration was made using $\alpha$-Fe $(6 \mu \mathrm{m})$ foil. Variable 
temperatures were obtained with an Oxford Spectromag $4000 \mathrm{M}$ cryostat connected to an ITC-503 Oxford Instruments temperature controller. To avoid saturation effects and optimize the signal-to-noise ratio, the sample thickness was $10 \mathrm{mg}$ of natural Fe $\mathrm{cm}^{-2}$.

2.2.7. Electronic Paramagnetic Resonance. EPR spectra were collected on a Bruker EMX-1572 spectrometer working at $9.39 \mathrm{GHz}$ (X-band) using polycrystalline samples of $\mathbf{1}$ at $298 \mathrm{~K}$.

2.2.8. Magnetic Measurements. Magnetic measurements were carried out using a Quantum Design Dynacool Physical Properties Measurement System (PPMS) equipped with a vibrating sample magnetometer (VSM). The dc data were collected under externally applied fields of $1 \mathrm{kOe}$ in the 1.8-300 $\mathrm{K}$ temperature range. Also, magnetization measurements at the variable field were performed at $1.8,3,5$, and $8 \mathrm{~K}$ from 0 to 90 $\mathrm{kOe}$. The magnetic signal from the sample holder was negligible to affect our data accuracy and was not considered. Diamagnetic corrections (estimated from Pascal constants) were considered. ${ }^{35}$ The simulation of the temperature-dependent magnetic susceptibility data was performed by exact diagonalization of the spin Hamiltonian employing the PHI software. ${ }^{36}$

\section{RESULTS AND DISCUSSION}

3.1. Synthesis. Concerning the synthesis of 1 , the organic ligand $\mathrm{H}_{3} \mathrm{IDC}$ can be considered as a polyprotic acid. Depending on the $\mathrm{pH}$ of the media, this ligand can be present in the final product with different protonation degrees (Scheme 1).

Scheme 1. $\mathrm{pK}_{\mathrm{a}}$ Values of the Organic Ligand $\mathrm{H}_{3}$ IDC

$\begin{array}{lll}\mathrm{H}_{3} \mathrm{IDC} & \leftrightharpoons \mathrm{H}_{2} \mathrm{IDC}^{-}+\mathrm{H}^{+} & \mathrm{pKa}_{1}=5.3 \\ \mathrm{H}_{2} \mathrm{IDC}^{-} & \leftrightharpoons \mathrm{HIDC}^{2-}+\mathrm{H}^{+} & \mathrm{pKa}_{2}=8.2 \\ \mathrm{HIDC}^{2-} & \leftrightharpoons \mathrm{IDC}^{3-}+\mathrm{H}^{+} & \mathrm{pKa}_{3}=11.8\end{array}$

The initial suspension of $\mathrm{H}_{3}$ IDC in an $\mathrm{H}_{2} \mathrm{O} / \mathrm{DMF}$ mixture gave a $\mathrm{pH}$ near 3 , indicating that the full protonated $\mathrm{H}_{3} \mathrm{IDC}$ should be the predominant species in this media. When triethylamine $\left(\mathrm{Et}_{3} \mathrm{~N} ; 36 \mathrm{mmol}\right)$ was added, the $\mathrm{pH}$ increased to 11 , causing a displacement of the equilibrium to the more reactive ionic species $\mathrm{HIDC}^{2-} / \mathrm{IDC}^{3-}$, which are now able to coordinate the $\mathrm{Fe}^{\mathrm{III}}$ centers. Then, at the end of the reaction, the acidification with glacial acetic acid $(87 \mathrm{mmol})$ decreased the $\mathrm{pH}$ of the solution to 4 . Regarding the $\mathrm{pH}$ fluctuation in the reaction and the different protonation degrees of the $\mathrm{H}_{3} \mathrm{IDC}$ ligand $\left(\mathrm{IDC}^{3-} / \mathrm{HIDC}^{2-} / \mathrm{H}_{2} \mathrm{IDC}^{-}\right)$, it is possible to infer that the assembly of iron(III) with the organic species should generate multiple possibilities for the final formula of $\mathrm{Fe}_{8}{ }_{8}{ }^{\mathrm{II}}$ cluster. Thus, an anionic $\left[\mathrm{Fe}_{8}(\mathrm{IDC})_{12}\right]^{12-}$, neutral $\left[\mathrm{Fe}_{8}(\mathrm{HIDC})_{12}\right]$, or cationic $\left[\mathrm{Fe}_{8}\left(\mathrm{H}_{2} \mathrm{IDC}\right)_{12}\right]^{12+}$ species could be considered as a product. Considering that the species of the ligand are dependent on the $\mathrm{pH}$, it is reasonable to infer that $\mathrm{IDC}^{3-}$ anion should be the predominant species at $\mathrm{pH}=11\left(\mathrm{p} K_{\mathrm{a} 3}=11.8\right)$, being also able to coordinate the $\mathrm{Fe}^{\mathrm{III}}$ cations to give the $\mathrm{Fe}_{8}$ cluster $\left[\mathrm{Fe}_{8}(\mathrm{IDC})_{12}\right]^{12-}$. Later, the $\mathrm{pH}$ decreases to 4 , causing the quantitative protonation of $\mathrm{Et}_{3} \mathrm{~N}\left(\mathrm{pK}_{\mathrm{a}}=10.8\right)$ needed to induce the crystallization of the anionic cluster, $\left[\mathrm{Fe}_{8}(\mathrm{IDC})_{12}\right]^{12-}$. The fact that the $\mathrm{Fe}_{8}$ cluster was assembled under a basic medium and crystallized under a acidic medium can be taken as evidence about the chemical stability of $\left[\mathrm{Fe}_{8}(\text { IDC })_{12}\right]^{12-}$ over a broad $\mathrm{pH}$ range.

Figure $\mathrm{S} 2$ shows the mass spectrum of 1 obtained by the linear ion trap in the range of $150-1500 \mathrm{~m} / z$. The base peak at $573 \mathrm{~m} /$ $z$ correlates very well with the adduct species
$\left\{\left[\mathrm{Fe}_{8}(\mathrm{IDC})_{12}\right]+8 \mathrm{H}\right\}^{4-}$. Other adducts species with lower intensities were also identified at 1147,764 , and $458 \mathrm{~m} / z$, which correlate with $\left\{\left[\mathrm{Fe}_{8}(\mathrm{IDC})_{12}\right]+10 \mathrm{H}\right\}^{2-}$, $\left\{\left[\mathrm{Fe}_{8}(\mathrm{IDC})_{12}\right]+9 \mathrm{H}\right\}^{3-}$, and $\left\{\left[\mathrm{Fe}_{8}(\mathrm{IDC})_{12}\right]+7 \mathrm{H}\right\}^{5-}$, respectively. This result corroborates that the anionic species $\left[\mathrm{Fe}_{8}(\mathrm{IDC})_{12}\right]^{12-}$ is the correct representation for the $\mathrm{Fe}_{8}$ cluster. ${ }^{37,3}$

3.2. X-ray Single-Crystal Structural Characterization. $\mathrm{X}$-ray single-crystal analysis reveals that $\mathbf{1}$ corresponds to a discreet octanuclear cluster forming a cubic polyhedron, which crystallizes in the highly symmetric Ibam orthorhombic system (Table 1). Each corner of the cube is occupied by one $\mathrm{Fe}^{\mathrm{III}}$

\section{Table 1. Crystallographic Refinement Data for 1}

\begin{tabular}{|c|c|}
\hline empirical formula & $\mathrm{C}_{162} \mathrm{H}_{300} \mathrm{~N}_{46} \mathrm{O}_{71} \mathrm{Fe}_{8}{ }^{a}$ \\
\hline formula weight $\left(\mathrm{g} \mathrm{mol}^{-1}\right)$ & $4475.86^{a}$ \\
\hline temperature $(\mathrm{K})$ & 293(2) \\
\hline crystal system & orthorhombic \\
\hline space group & Ibam \\
\hline$a(\AA)$ & $18.051(8)$ \\
\hline$b(\AA)$ & $29.079(13)$ \\
\hline$c(\AA)$ & $33.766(15)$ \\
\hline$\alpha\left(^{\circ}\right)$ & 90 \\
\hline$\beta\left({ }^{\circ}\right)$ & 90 \\
\hline$\gamma\left(\left(^{\circ}\right)\right.$ & 90 \\
\hline volume $\left(\AA^{3}\right)$ & $17,724(13)$ \\
\hline$Z$ & 4 \\
\hline$\rho_{\text {calc }}\left(\mathrm{g} / \mathrm{cm}^{3}\right)$ & 0.856 \\
\hline$\mu\left(\mathrm{mm}^{-1}\right)$ & 0.692 \\
\hline$F(000)$ & 4528.0 \\
\hline crystal size $\left(\mathrm{mm}^{3}\right)$ & $0.986 \times 0.363 \times 0.274$ \\
\hline radiation & Mo $\mathrm{K} \alpha(\lambda=0.71073)$ \\
\hline $2 \theta$ range for data collection $\left(^{\circ}\right)$ & $5.954-52$ \\
\hline index ranges & $-22 \leq h \leq 22,-35 \leq k \leq 35,-41 \leq l \leq 41$ \\
\hline reflections collected & 67,448 \\
\hline independent reflections & $8864\left[R_{\text {int }}=0.0848, R_{\text {sigma }}=0.0601\right]$ \\
\hline data/restraints/parameters & $8864 / 0 / 320$ \\
\hline goodness-of-fit on $F^{2}$ & 1.297 \\
\hline final $R$ indices $[I \geq 2 \sigma(I)]$ & $R 1=0.1537, \mathrm{w} R 2=0.3714$ \\
\hline final $R$ indices [all data] & $R 1=0.2003, \mathrm{w} R 2=0.4078$ \\
\hline largest diff. peak/hole $\left(\mathrm{e} \AA^{-3}\right)$ & $2.08 /-1.05$ \\
\hline
\end{tabular}

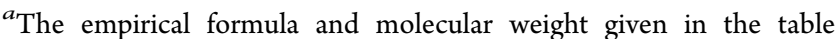
consider the counterions and solvate molecules determined by all the analysis techniques used in the experimental section.

center (Figure 1a), being the edges organic ligands. Continuous shape measurement (CShM) was used to evaluate the distortion of the cube. The iron moiety was compared with an ideal cube using the SHAPE software, ${ }^{39}$ obtaining a CShM value of 0.004 and confirming an almost perfect cubic arrangement of the coordination cluster (Table S3). This cube is obtained by the asymmetric unit containing two crystallographically independent iron centers and three full deprotonated IDC $^{3-}$ ligands. $\mathrm{Fe}(1)$ and $\mathrm{Fe}(2)$ present the same coordination environment, $\mathrm{FeN}_{3} \mathrm{O}_{3}$, produced by the coordination of three $\kappa \mathrm{N}, \mathrm{O}-\mathrm{IDC}^{3-}$ molecules, which also form three independent FeNCCO chelate rings (Figure $1 \mathrm{~b}$ ). The geometry of each $\mathrm{FeN}_{3} \mathrm{O}_{3}$ moiety was also compared with an ideal octahedron using the SHAPE. CShM values of 1.13 and 1.00 were obtained for $\mathrm{Fe}(1)$ and $\mathrm{Fe}(2)$, respectively, confirming that the geometry of both cations is well described as octahedron (Tables S4 and S5). On the other hand, as depicted in Figure $1 \mathrm{c}$, the $\mathrm{IDC}^{3-}$ anion is 

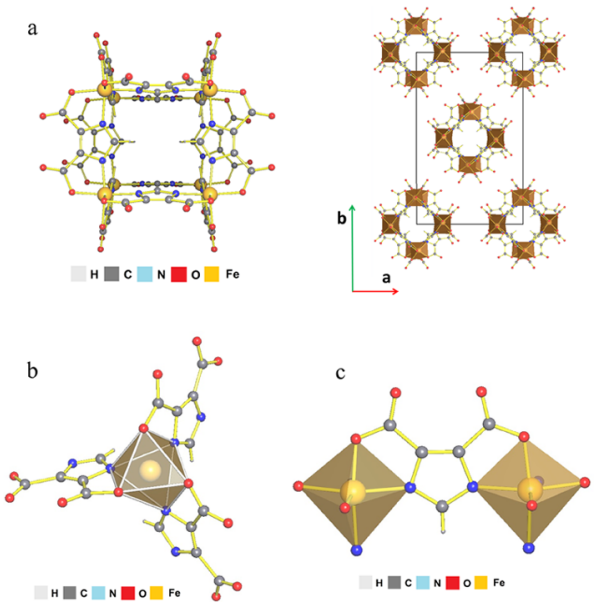

Figure 1. (a) Molecular structure of 1 and view of the packing through the $c$ axis. (b) Coordination environment of $\mathrm{Fe}^{\mathrm{III}}$ centers in $\mathbf{1}$ and (c) $\mu$ $1 \kappa^{2} N, O: 2 \kappa^{2} N^{\prime}, O^{\prime \prime \prime}$ bis-chelating bridge mode of IDC $^{3-}$.

acting as the $\mu-1 \kappa^{2} N, O: 2 \kappa^{2} N^{\prime}, O^{\prime \prime \prime}$-IDC ${ }^{3-}$ bis-chelating bridge, leading to an intercation distance of $\mathrm{Fe}(1) \cdots \mathrm{Fe}(2)=6.3754(3)$ $\AA$ (Figure 1c). Additionally, each [Fe(IDC) 3 ] moiety is chiral, being the handedness of $\mathrm{Fe}(1) \Lambda$ and $\mathrm{Fe}(2) \Delta$. Because of the $\Lambda-\Delta$ alternating arrangement, a centrosymmetric compound is obtained. In compound $\mathbf{1}$, the $\mathrm{Fe}-\mathrm{N}$ and $\mathrm{Fe}-\mathrm{O}$ bond distances are in the range of $2.028(7)-2.093(7) \AA$ and $1.985(6)-$ 2.003(7) $\AA$ for $\mathrm{Fe}(1)$ and in the range of $2.069(7)-2.098(7) \AA$ and 1.979(7)-2.005(7) for $\mathrm{Fe}(2)$. Usually, in coordination compounds, the bond distance can be associated with the oxidation and spin state of the cation. For example, Angaridis et al. reported two molecular systems $\left[\mathrm{Fe}\left(3,5-{ }^{t} \mathrm{Bu}_{2}\right.\right.$ salpn $)$ ( Me D C B I ) Fe $\left.\left(3,5-{ }^{t} \mathrm{Bu}_{2}-\mathrm{salpn}\right)\right]$ and $\{[\mathrm{Fe}-$ $\left(3,5-{ }^{t} \mathrm{Bu}_{2}\right.$ salpn $\left.\left.)\right]_{2}(\mathrm{HDCBI})\right\}\left(3,5-{ }^{t} \mathrm{Bu}_{2}\right.$ salpn $=$ dianion of $1,3-$ bis-[(di-tert-butylsalicylidene)amino] propane); $\mathrm{H}_{2} \mathrm{MeDCBI}=$ 4,5-dicarboxy-1-methyl- $1 \mathrm{H}$-imidazole; $\mathrm{H}_{3} \mathrm{DCBI}=4,5$-dicarboxyimidazole).${ }^{40}$ Both compounds are based on $\mathrm{Fe}^{\mathrm{III}}$ in a high-spin state (HS), having an $\mathrm{FeN}_{3} \mathrm{O}_{3}$ environment formed by $\kappa^{2} N, \mathrm{O}^{\prime}$ $\mathrm{HDCB}^{2-} / \kappa^{2} N, \mathrm{O}^{\prime}-\mathrm{MeDCBI}^{2-}$ and $\kappa^{4} \mathrm{O}, N, N^{\prime}, \mathrm{O}^{\prime}-3,5-{ }^{t} \mathrm{Bu}_{2}$ salpn, being the cations bridged by $\mu-1 \kappa^{2} N, O: 2 \kappa^{2} N^{\prime}, O^{\prime \prime \prime}$-imidazole ligand as in 1 and presenting $\mathrm{Fe}-\mathrm{N}=2.126(3)-2.107(1)$ and $\mathrm{Fe}-\mathrm{O}=1.883(2) \AA-2.223 \AA$ bond distances. ${ }^{40}$ Also, in other imidazoles $\mathrm{Fe}^{\mathrm{III}}-\mathrm{HS}$ compounds, the average $\mathrm{Fe}-\mathrm{N}$ is $2.091 \AA .{ }^{41}$ All these data permitted us to infer that the $\mathrm{Fe}(1)$ and $\mathrm{Fe}(2)$ cations present in $\mathbf{1}$ can be assigned as $\mathrm{Fe}^{\mathrm{III}}$-HS. Therefore, the iron cluster previously determined from structural X-ray measurements can be represented as $\left[\mathrm{Fe}_{8}(\mathrm{IDC})_{12}\right]^{12-}$.

Literature reports different analogous $\mathrm{M}_{8}-\mathrm{H}_{n} \mathrm{IDC}^{n-3}$ compounds based on other transition metal cations $(\mathbf{2}-\mathbf{1 8})$, which are summarized in Table 2. For example, Liu et al. obtained under solvothermal conditions an anionic $\mathrm{Ni}^{\mathrm{II}}$ cluster, $\left[\mathrm{Ni}_{8}(\text { HIDC })_{12}\right]^{8-}(2)$. This $\mathrm{Ni}_{8}{ }^{\mathrm{II}}$ cube is surrounded by a large number of solvent molecules and protonated 4,4'-trimethylenedipiperidine as countercations. ${ }^{42}$ Likewise, by a solvothermal reaction, $\mathrm{Xu}$ et al. reported the synthesis of another $0 \mathrm{D} \mathrm{Ni}{ }^{\mathrm{II}}$ neutral cubic cluster $\left[\left(\mathrm{Ni}_{8}\left(\mathrm{H}_{2} \mathrm{IDC}\right)_{8}(\mathrm{HIDC})_{4}\right)\right] \cdot 8\left(\mathrm{C}_{2} \mathrm{H}_{5} \mathrm{OH}\right)$. $18\left(\mathrm{H}_{2} \mathrm{O}\right)(3)$, in which the $\mathrm{H}_{3} \mathrm{IDC}$ ligand is found both as diand monoprotonated species and also surrounded by solvate molecules. ${ }^{43}$ Meanwhile, Cheng et al. reported the synthesis at room temperature of another anionic cluster without solvate molecules $\left[\mathrm{Me}_{4} \mathrm{~N}\right]_{20}\left[\mathrm{Co}_{8}(\mathrm{IDC})_{12}\right](4),{ }^{44}$ but unfortunately, the crystalline structure was not reported in the publication. Moreover, extended networks obtained from the $\mathrm{M}_{8}$ anionic cluster and stabilized by the incorporation of a second metal cation have also been reported (5-10). In these cases, the imidazole ligand is present in the full deprotonated form $\left(\mathrm{IDC}^{3-}\right)$, giving a cluster with a highly negative charge. For compounds 6-10, the anionic cluster is stabilized by the linkage of alkaline cations to the carboxylate groups belonging to the imidazole ligand. ${ }^{45}$ Besides, Cheng et al. reported a mixedvalence $\mathrm{Co}^{\mathrm{II}} / \mathrm{Co}^{\mathrm{III}}$ cubic cluster forming a $1 \mathrm{D}$ heterometallic coordination polymer $[\mathrm{Ni}(\text { cyclam })]_{4}[\mathrm{Ni}($ cyclam $)$ $\left.\left(\mathrm{H}_{2} \mathrm{O}\right)_{2}\right]_{2}\left\{[\mathrm{Ni}(\right.$ cyclam $\left.)]\left[\mathrm{Co}_{8}(\mathrm{IDC})_{12}\right]\right\} \cdot 41 \mathrm{H}_{2} \mathrm{O}$ (5). This extended compound is assembled by the $\left[\mathrm{Co}_{6}{ }^{\mathrm{II}} \mathrm{Co}_{2}{ }^{\mathrm{III}}(\mathrm{IDC})_{12}\right]^{14-}$

Table 2. Summary of $M_{8}$ Cubes Reported in the Literature

\begin{tabular}{|c|c|c|c|c|c|}
\hline formula of the compound & synthesis type & dimension & charge of the cluster & $\mathrm{H}_{3} \mathrm{IDC}$ species & ref \\
\hline$\left[\mathrm{Et}_{3} \mathrm{NH}\right]_{12}\left[\mathrm{Fe}_{8}(\mathrm{IDC})_{12}\right] \cdot 10 \mathrm{DMF} \cdot 13 \mathrm{H}_{2} \mathrm{O}(\mathbf{1})$ & R.T..$^{e}$ & OD & -12 & $\mathrm{IDC}^{3-}$ & this work \\
\hline $\mathrm{Ni}_{8}(\mathrm{HIDC})_{12}\left(\mathrm{H}_{2} \mathrm{TMDP}\right)_{4}(\mathrm{DMF})_{4}(\mathrm{EtOH})_{4}\left(\mathrm{H}_{2} \mathrm{O}\right)_{6}{ }^{a}(2)$ & solvothermal & OD & -8 & $\mathrm{HIDC}^{2-}$ & 42 \\
\hline$\left[\left(\mathrm{Ni}_{8}\left(\mathrm{H}_{2} \mathrm{IDC}\right)_{8}(\mathrm{HIDC})_{4}\right)\right] \cdot 8\left(\mathrm{C}_{2} \mathrm{H}_{5} \mathrm{OH}\right) \cdot 18\left(\mathrm{H}_{2} \mathrm{O}\right)$ & solvothermal & $0 \mathrm{D}$ & 0 & $\mathrm{H}_{2} \mathrm{IDC}^{-} / \mathrm{HIDC}^{2-}$ & 43 \\
\hline$\left[\mathrm{Me}_{4} \mathrm{~N}\right]_{20}\left[\mathrm{Co}_{8}(\mathrm{IDC})_{12}\right]^{b}(4)$ & R.T. & OD & -20 & $\mathrm{IDC}^{3-}$ & 44 \\
\hline$[\mathrm{Ni}(\text { cyclam })]_{4}\left[\mathrm{Ni}(\text { cyclam })\left(\mathrm{H}_{2} \mathrm{O}\right)_{2}\right]_{2}(\mathbf{5})$ & R.T. & $1 \mathrm{D}$ & -14 & IDC $^{3-}$ & 44 \\
\hline \multicolumn{6}{|l|}{$[\mathrm{Ni}($ cyclam $)]\left[\mathrm{Co}_{8}(\mathrm{IDC})_{12}\right]$}$\cdot 41 \mathrm{H}_{2} \mathrm{O}^{c}$ \\
\hline $\mathrm{K}_{20}\left[\mathrm{Ni}_{8} \mathrm{IDC}_{12}\right] \cdot 74\left(\mathrm{H}_{2} \mathrm{O}\right)(6)$ & R.T. & $3 \mathrm{D}$ & -20 & IDC $^{3-}$ & 43 \\
\hline $\mathrm{K}_{20}\left[\mathrm{Ni}_{8} \mathrm{IDC}_{12}\right] \cdot 50\left(\mathrm{H}_{2} \mathrm{O}\right)(7)$ & R.T. & $3 \mathrm{D}$ & -20 & IDC $^{3-}$ & 43 \\
\hline $\mathrm{K}_{20}\left[\mathrm{Ni}_{8} \mathrm{IDC}_{12}\right] \cdot 29\left(\mathrm{H}_{2} \mathrm{O}\right)(8)$ & R.T. & $3 \mathrm{D}$ & -20 & $\mathrm{IDC}^{3-}$ & 43 \\
\hline$\left\{\left[\mathrm{Li}_{11}\left(\mathrm{Ni}_{8} \mathrm{IDC}_{12}\right)\left(\mathrm{H}_{2} \mathrm{O}\right)_{12}\right] \mathrm{Li}_{9}\left(\mathrm{H}_{2} \mathrm{O}\right)_{20}\right\}$ & solvothermal & $3 \mathrm{D}$ & -20 & IDC $^{3-}$ & 45 \\
\hline$\left\{\left[\mathrm{Na}_{20}\left(\mathrm{Ni}_{8} \mathrm{IDC}_{12}\right)\left(\mathrm{H}_{2} \mathrm{O}\right)_{28}\right]\left(\mathrm{H}_{2} \mathrm{O}\right)_{13}\left(\mathrm{CH}_{3} \mathrm{OH}\right)_{2}\right\}$ & solvothermal & $3 \mathrm{D}$ & -20 & $\mathrm{IDC}^{3-}$ & 45 \\
\hline $\mathrm{Zn}_{12}(\text { guanidinium })_{8}(\mathrm{IDC})_{8}(\mathrm{HIDC})_{4} \cdot(\mathrm{DMF})_{8}\left(\mathrm{H}_{2} \mathrm{O}\right)_{3}(11)$ & solvothermal & $3 \mathrm{D}$ & -16 & $\mathrm{HIDC}^{2-} / \mathrm{IDC}^{3-}$ & 46 \\
\hline $\mathrm{Cd}_{8} \mathrm{Na}_{8}(\mathrm{HIDC})_{8}(\mathrm{IDC})_{4}\left(\mathrm{H}_{2} \mathrm{Pip}\right)_{2} \cdot(\mathrm{EtOH})_{5}\left(\mathrm{H}_{2} \mathrm{O}\right)_{37}^{d}(12)$ & solvothermal & $3 \mathrm{D}$ & -12 & $\mathrm{HIDC}^{2-} / \mathrm{IDC}^{3-}$ & 46 \\
\hline $\mathrm{Zn}_{8} \mathrm{~K}_{8}(\mathrm{HIDC})_{12}(\mathrm{DMF})_{5}\left(\mathrm{H}_{2} \mathrm{O}\right)_{16}(\mathbf{1 3})$ & solvothermal & $3 \mathrm{D}$ & -8 & $\mathrm{HIDC}^{2-}$ & 46 \\
\hline $\mathrm{Cd}_{8} \mathrm{~K}_{8}(\mathrm{HIDC})_{12}(\mathrm{DMF})_{5}\left(\mathrm{H}_{2} \mathrm{O}\right)_{16}(\mathbf{1 4})$ & solvothermal & $3 \mathrm{D}$ & -8 & $\mathrm{HIDC}^{2-}$ & 46 \\
\hline $\mathrm{Co}_{8} \mathrm{~K}_{8}(\mathrm{HIDC})_{12}(\mathrm{DMF})_{5}\left(\mathrm{H}_{2} \mathrm{O}\right)_{16}(\mathbf{1 5})$ & solvothermal & $3 \mathrm{D}$ & -8 & HIDC $^{2-}$ & 46 \\
\hline $\mathrm{Mn}_{8} \mathrm{~K}_{8}(\mathrm{HIDC})_{12}(\mathrm{DMF})_{5}\left(\mathrm{H}_{2} \mathrm{O}\right)_{16}(\mathbf{1 6})$ & solvothermal & $3 \mathrm{D}$ & -8 & HIDC $^{2-}$ & 46 \\
\hline$\left[\mathrm{Cr}_{4} \mathrm{In}_{4}(\mathrm{HIDC})_{12}\right] \cdot \mathrm{H}_{2} \mathrm{O}(17)$ & solvothermal & OD & 0 & $\mathrm{HIDC}^{2-}$ & 47 \\
\hline$\left[\mathrm{Cr}_{7.28} \mathrm{In}_{0.72}(\mathrm{HIDC})_{12}\right] \cdot \mathrm{H}_{2} \mathrm{O}(\mathbf{1 8})$ & solvothermal & OD & 0 & $\mathrm{HIDC}^{2-}$ & 47 \\
\hline
\end{tabular}

${ }^{a} \mathrm{H}_{2} \mathrm{TMDP}^{2+}=4,4^{\prime}$-trimethylenedipiperidinium. ${ }^{b} \mathrm{Me}_{4} \mathrm{~N}^{+}=$tetramethylammonium, crystalline structure not reported. ${ }^{c}$ cyclam $=1,4,8,11-$ tetraazacyclotetradecane. ${ }^{d} \mathrm{H}_{2} \mathrm{Pip}^{2+}=$ piperazinium. ${ }^{e} \mathrm{R} . \mathrm{T} .=$ room temperature. 
a
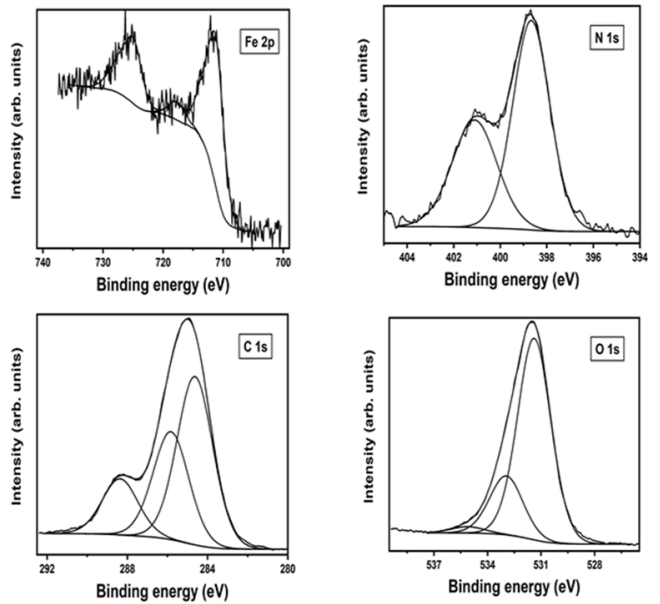

b

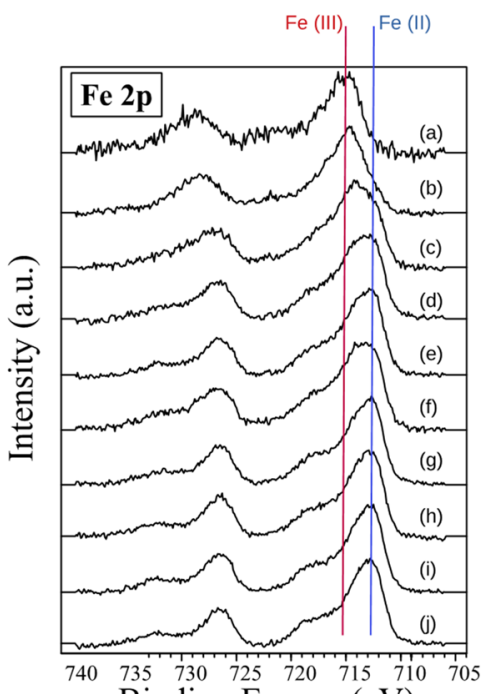

c

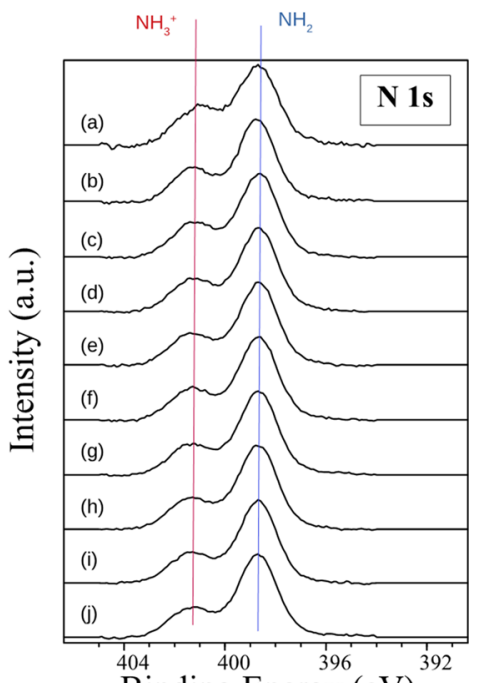

Binding Energy (eV)

Figure 2. (a) High-resolution Fe 2p, N 1s, C 1s, and O 1s XPS spectra. (b) Fe 2p spectra recorded after different exposure times to the X-ray beam of the XPS spectrometer: (a) $7 \mathrm{~min}$, (b) $42 \mathrm{~min}$, (c) $107 \mathrm{~min}$, (d) $172 \mathrm{~min}$, (e) $237 \mathrm{~min}$, (f) $302 \mathrm{~min}$, (g) $367 \mathrm{~min}$, (h) $432 \mathrm{~min},(\mathrm{i}) 497 \mathrm{~min}$, and (j) 562 min. Note the progressive transformation of the initial Fe ${ }^{\mathrm{III}}$-HS species in an Fe $\mathrm{F}^{\mathrm{II}}$-HS species. (c) N $1 \mathrm{~s}$ spectra recorded after different exposure times to the X-ray beam of the XPS spectrometer: (a) $12 \mathrm{~min}$, (b) $77 \mathrm{~min}$, (c) $142 \mathrm{~min}$, (d) $205 \mathrm{~min}$, (e) $270 \mathrm{~min}$, (f) $367 \mathrm{~min}$, (g) $432 \mathrm{~min}$, (h) $497 \mathrm{~min}$, (i) 562 $\mathrm{min}$, and (j) $592 \mathrm{~min}$. Note how the intensity of the initial triethylammonium $\left(\mathrm{Et}_{3} \mathrm{NH}^{+}\right)$species decreases with increasing $\mathrm{X}$-ray irradiation times.

cluster, which is coordinated by the carboxylate group to the $[\mathrm{Ni}(\text { cyclam })]^{2+}$ complexes. $^{44}$

On the other hand, Alkordi et al. reported six 3D networks built from $M_{8}{ }^{I I}$ anionic cubes $\left(\mathbf{1 1 - 1 6 ) .} .^{46}\right.$ $\mathrm{Zn}_{12}$ (guanidinium $)_{8}(\mathrm{IDC})_{8}(\mathrm{HIDC})_{4} \cdot(\mathrm{DMF})_{8}\left(\mathrm{H}_{2} \mathrm{O}\right)_{3} \mathbf{1 1}$ and $\mathrm{Cd}_{8} \mathrm{Na}_{8}(\mathrm{HIDC})_{8}(\mathrm{IDC})_{4}\left(\mathrm{H}_{2} \mathrm{Pip}\right)_{2}(\mathrm{EtOH})_{5}\left(\mathrm{H}_{2} \mathrm{O}\right)_{37} 12$ contain $\mathrm{HIDC}^{2-}$ and $\mathrm{IDC}^{3-}$ species as ligands. In the case of 11, the negative charge is balanced by both guanidinium and zinc cations, being the zinc cations also coordinating the carboxylates groups belonging to the anionic cubes originating in this form the $3 \mathrm{D}$ structure. For 12, sodium and a protonated amine (piperazinium) are also balancing the charge of the cubic cluster. The authors also report a series of compounds $\mathrm{M}_{8} \mathrm{~K}_{8}(\mathrm{HIDC})_{12}(\mathrm{DMF})_{5}\left(\mathrm{H}_{2} \mathrm{O}\right)_{16}\left(\mathrm{M}=\mathrm{Zn}^{\mathrm{II}}, \mathrm{Cd}^{\mathrm{II}}, \mathrm{Co}^{\mathrm{II}}\right.$, and $\left.\mathrm{Mn}^{\mathrm{II}}\right)(13-16)$, containing only the $\mathrm{HIDC}^{3-}$ species as a ligand, but in these cases, only alkaline cations are stabilizing the $\left[\mathrm{M}_{8}(\mathrm{HIDC})_{12}\right]^{8-}$ cluster in the $3 \mathrm{D}$ networks. The two last examples (17 and 18) were reported by Zhai et al. ${ }^{47}$ and correspond to $\mathrm{In}^{\mathrm{III}}-\mathrm{Cr}^{\mathrm{III}}$ heterometallic $0 \mathrm{D}$ cubes $\left[\mathrm{Cr}_{4} \mathrm{In}_{4}(\mathrm{HIDC})_{12}\right] \cdot \mathrm{H}_{2} \mathrm{O}$ and $\left[\mathrm{Cr}_{7.28} \mathrm{In}_{0.72}(\mathrm{HIDC})_{12}\right] \cdot \mathrm{H}_{2} \mathrm{O}$, being neutral species and only including the $\mathrm{HIDC}^{2-}$ in the structure.

In our case, although the molecular structure of the $\mathrm{Fe}_{8}{ }^{\mathrm{III}}$ core was well identified by $\mathrm{X}$-ray single-crystal analysis due to the size of the cluster and the high symmetry of the cell, part of the electronic density surrounding the cluster remained invisible for this technique, as has also been reported in an analogous cobalt octanuclear cluster. ${ }^{44}$ However, according to the examples mentioned above, the full deprotonated IDC ${ }^{3-}$ species generates $\mathrm{M}_{8}$ cubes with the highest negative charge, which is stabilized by other metal cations or bulky protonated amines. Then, 12 counterions must be present in the compound to neutralize the negative charge of the resulting $\left[\mathrm{Fe}_{8}(\mathrm{IDC})_{12}\right]^{12-}$ cluster. Since no additional iron centers were found in the intercluster space, only the triethylammonium cation should be acting as a counterion. This counterion also provides enough steric hindrance to avoid the assembly between the iron clusters, thus producing a molecular crystal packing for 1 , as was also reported for the $\mathrm{Ni}_{8}{ }^{\mathrm{II}}$ analogous system with 4,4'-trimethylenedipiperidinium. ${ }^{42}$ Accordingly, XPS, TG, and FTIR were performed to complement the structural characterization.

3.3. XPS. To gather more information about the chemical composition of 1, Fe 2p, N 1s, C 1s, and $\mathrm{O}$ 1s high-resolution XPS spectra were also collected (Figure $2 a$ ). The Fe $2 p$ spectrum consists of an asymmetric spin-orbit doublet with binding energies of the $\mathrm{Fe} 2 \mathrm{p}_{3 / 2}$ and $\mathrm{Fe} 2 \mathrm{p}_{1 / 2}$ core levels of 711.5 and $725.2 \mathrm{eV}$, respectively, and a small shake-up satellite at $717.8 \mathrm{eV}$. The shape of the spectrum, the binding energies of its different components, and the presence of the small satellite are all characteristic of iron in $3+$ oxidation state and high-spin configuration, ${ }^{48,49}$ confirming the observation in the structural characterization. The $\mathrm{N}$ 1s spectrum was best-fitted to two contributions. The major one, located at a binding energy of $398.7 \mathrm{eV}$, can be ascribed to an amine-type or aromatic-type N$\mathrm{H}$ bond belonging to the imidazole ring of the organic ligand. ${ }^{50,51}$ The higher binding energy component at $401.1 \mathrm{eV}$ is characteristic of a quaternary nitrogen species, ${ }^{50,51}$ which must belong to the triethylammonium $\left(\mathrm{Et}_{3} \mathrm{NH}^{+}\right)$present in the intercluster space of $\mathbf{1}$ and acting as a countercation. A fit considering also the contribution to the $\mathrm{N}$ 1s spectrum of a ternary amine was not successful, discarding the presence of trimethylamine in the final product. The $\mathrm{C} 1 \mathrm{~s}$ spectrum contains three different carbon species at 284.6, 285.8, and $288.4 \mathrm{eV}$, which can be associated with $\mathrm{C}-\mathrm{C}$ or $\mathrm{C}-\mathrm{H}$ bonds; $\mathrm{C}-\mathrm{N}, \mathrm{C}-\mathrm{O}$, $\mathrm{C}=\mathrm{N}$, or $\mathrm{C} \equiv \mathrm{N}$ bonds; and $\mathrm{O}-\mathrm{C}=\mathrm{O}$ bonds, respectively. ${ }^{50,51}$ The $\mathrm{O}$ 1s spectrum contains three contributions. The main one at $531.4 \mathrm{eV}$ can be associated with $\mathrm{C}=\mathrm{O}$ bonds in $\mathrm{O}=\mathrm{C}-\mathrm{O}$ groups, while the second one at $533.0 \mathrm{eV}$ may correspond to $\mathrm{C}-$ $\mathrm{O}$ bonds in $\mathrm{O}=\mathrm{C}-\mathrm{O}$ groups. $^{50,51}$ The minor component at $535.0 \mathrm{eV}$ might be ascribed to a small oxygen satellite.

All the identified bonds are part of the IDC $^{3-}$ anionic ligand present in the cluster $\left[\mathrm{Fe}_{8}(\mathrm{IDC})_{12}\right]^{12-}$. Nevertheless, from a 


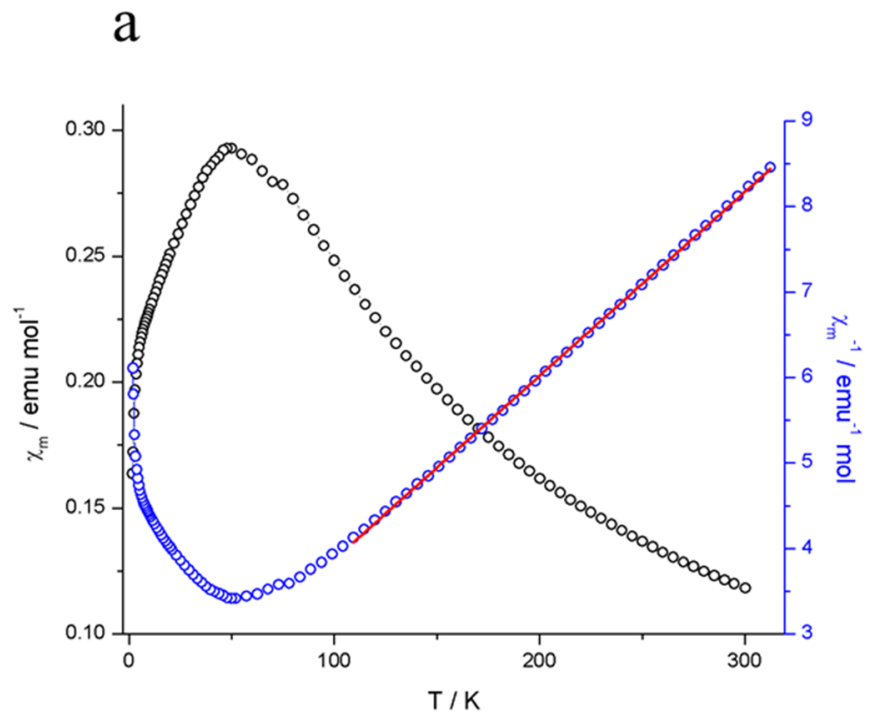

b
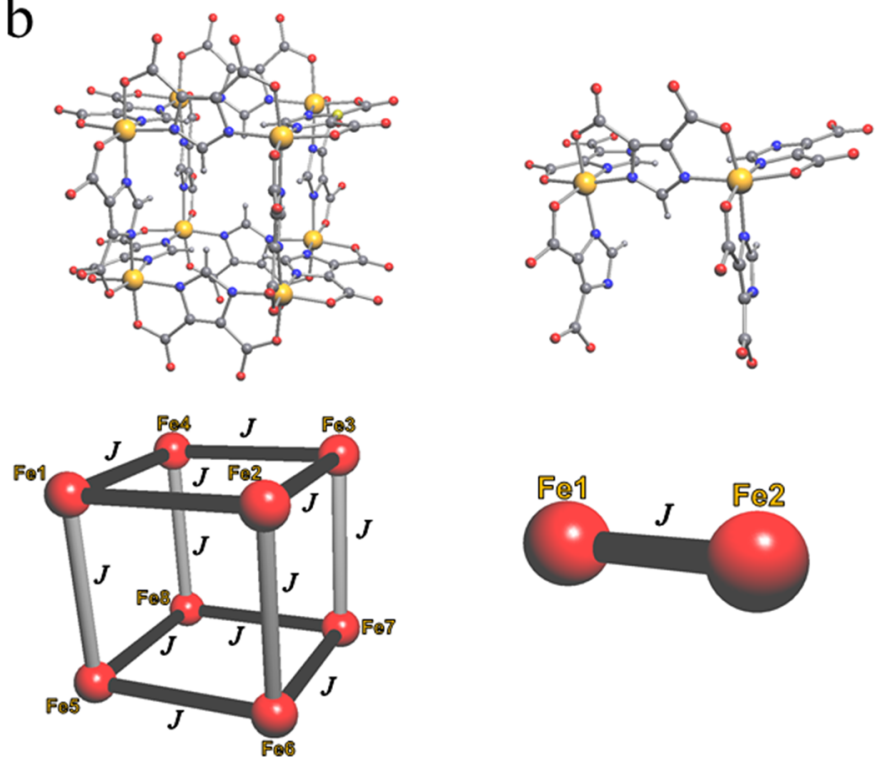

Figure 3. (a) Plots of $\chi_{\mathrm{m}}$ vs $T$ and $\chi_{\mathrm{m}}{ }^{-1}$ vs $T$ for $\mathbf{1}$. (b) Images of magnetic pathways for the $\mathrm{Fe}_{8}$ moiety in $\mathbf{1}$ and the binuclear $\mathrm{Fe}_{2}$ simplified model.

chemical viewpoint, the presence of a quaternary nitrogen species corroborates that triethylammonium $\left(\mathrm{Et}_{3} \mathrm{NH}^{+}\right)$is the countercation of the anionic iron cluster, which is also consistent with the reaction condition used to obtain 1 . Therefore, the molecular structure of the iron cluster is deduced to be $\left[\mathrm{Et}_{3} \mathrm{NH}\right]_{12}\left[\mathrm{Fe}_{8}(\mathrm{IDC})_{12}\right]$.

An important fact that was found during the development of this work is that the sample is very sensitive to the irradiation by the X-rays of the XPS spectrometer and that it undergoes important chemical changes after relatively short irradiation times. To minimize the occurrence of these changes, we used a low power in the $\mathrm{X}$-ray gun ( $100 \mathrm{~W}$ against the more usual 300 $\mathrm{W})$ and slightly higher pass energy $(30 \mathrm{eV}$ vs the usual $20 \mathrm{eV})$ to record the data. Using a constant pass energy of $30 \mathrm{eV}$ instead of $20 \mathrm{eV}$ allows recording the spectra with a larger number of counts in a given time without compromising too much the energy resolution. So, for the Fe $2 \mathrm{p}$ spectrum shown in Figure $2 \mathrm{~b}$, we used only one scan (less than 5 min of irradiation) since increasing the number of scans can lead to chemical changes.Figure $2 \mathrm{~b}$ collects the Fe $2 \mathrm{p}$ spectra recorded after several increasing irradiation times. It is evident that, even after short irradiation times (see spectra (b) and (c) in Figure 2b), the lines of the Fe $2 p$ spectrum shift to lower binding energies and a strong shake-up satellite starts developing at around $714 \mathrm{eV}$. These results clearly indicate that the initial $\mathrm{Fe}^{\mathrm{III}}-\mathrm{HS}$ is progressively reduced to an $\mathrm{Fe}^{\mathrm{II}}$-HS species upon X-ray irradiation. In fact, the spectra recorded at intermediate irradiation times contain both $\mathrm{Fe}^{\mathrm{II}}-\mathrm{HS} / \mathrm{Fe}^{\mathrm{III}}-\mathrm{HS}$ contributions. After long irradiation times (Figure $2 \mathrm{~b}$ ), the Fe 2 p spectrum only shows the presence of $\mathrm{Fe}^{\mathrm{II}}$-HS species. ${ }^{49}$ Important changes are also observed in the $\mathrm{N} 1 \mathrm{~s}$ spectra $2 \mathrm{c}$. In this case, a decrease in the intensity of the protonated $\mathrm{Et}_{3} \mathrm{NH}^{+}$species is observed upon $\mathrm{X}$-ray irradiation. However, and contrary to the iron case, the quaternary nitrogen species appears to be more resilient, as it is still present after long irradiation times. The mechanisms giving place to chemical changes under X-ray irradiation in XPS are complex and have been commented in detail elsewhere. ${ }^{51}$ In particular, in the case of the reduction of metal cations in oxides, interionic Auger decay processes appear to play an important role. ${ }^{50}$ Among all the chemical changes reported, the degradation of quaternary nitrogen species (deprotonation) has also been reported for some organic compounds. ${ }^{50}$ The results are relevant because they stress the need of being extremely careful when recording XPS data for this type of compound. Otherwise, erroneous conclusions can be drawn from the recorded data.

3.4. FTIR and Thermogravimetric Measurements. Figure S3a,b shows the infrared spectra of $\mathbf{1}$, compared with those of trimethylamine in acidic media and $N, N$-dimethylformamide. A clear match of the first two spectra between 3000 and $2400 \mathrm{~cm}^{-1}$ can be observed, in agreement with the presence of the cationic $\mathrm{Et}_{3} \mathrm{NH}^{+}$species in $\mathbf{1}$ (Figure S3a). Also, the strong absorption at $1680 \mathrm{~cm}^{-1}$ (observed in the spectrum of 1 ) is exactly in the same position of the $\mathrm{C}=\mathrm{O}$ vibration associated with DMF molecules (Figure S3b), indicating that this molecule must also be present in the final formula. Additionally, thermogravimetric analysis was performed under a nitrogen atmosphere (Figure S4) to characterize the presence of solvent molecules and thermal stability of $\mathbf{1}$. The cluster is stable until $250{ }^{\circ} \mathrm{C}$, showing two weight losses of $5.2 \%\left(30-90{ }^{\circ} \mathrm{C}\right)$ and $16.1 \%\left(190-250{ }^{\circ} \mathrm{C}\right)$ associated with solvate molecules. Considering that both $\mathrm{H}_{2} \mathrm{O}$ and DMF were used as a solvent in the synthesis of $\mathbf{1}$ and as it has been reported for other compounds, ${ }^{52}$ it is reasonable to assign the first loss to the release of 13 water molecules $(5.2 \%)$ and the second one to 10 DMF molecules (16.3\%). At higher temperatures, a third weight loss of $30.2 \%\left(250-360{ }^{\circ} \mathrm{C}\right)$ is observed. Literature data show that triethylammonium salts (triethylammonium bis-7,7,8,8tetracyanoquinodimethane) have a thermal decomposition process between 195 and $220{ }^{\circ} \mathrm{C} .{ }^{53}$ Additionally, the inorganic cluster $\left(\left[(\mathrm{HTEA})(\mathrm{TEA})_{0.75}\right]_{2}\left[\mathrm{PSb}_{2}{ }^{\mathrm{III}} \mathrm{Mo}_{5}{ }^{\mathrm{V}} \mathrm{Mo}_{7}{ }^{\mathrm{VI}} \mathrm{O}_{40}\right]\right)$ shows a continuous weight loss (14.6\%) between 44 and $573{ }^{\circ} \mathrm{C}$, which is attributed by the authors to the release of tryethylamine. ${ }^{54}$ Therefore, the loss of $30.2 \%$ can be associated to the release of 12 trimethylamine (27.4\%) belonging to $12 \mathrm{Et}_{3} \mathrm{NH}^{+}$acting as counterions. ${ }^{55}$ Considering the solvate molecules, the final formula of $\mathbf{1}$ is $\left[\mathrm{Et}_{3} \mathrm{NH}\right]_{12}\left[\mathrm{Fe}_{8}(\mathrm{IDC})_{12}\right] \cdot 10 \mathrm{DMF} \cdot 13 \mathrm{H}_{2} \mathrm{O}$, which correlates very well with the elemental analysis given in the experimental section (section 2.1.1). With these results in mind, Mössbauer spectroscopy, electronic paramagnetic resonance, 
and magnetic susceptibility measurements were also performed to characterize the properties of $\left[\mathrm{Et}_{3} \mathrm{NH}\right]_{12}\left[\mathrm{Fe}_{8}(\mathrm{IDC})_{12}\right]$. 10DMF. $13 \mathrm{H}_{2} \mathrm{O}$.

3.5. EPR and Magnetic Measurements. The X-band EPR spectrum at room temperature of a polycrystalline sample of 1 shows a broad signal characteristic of an $\mathrm{Fe}^{\mathrm{III}}-\mathrm{HS}$ ion with $S=5$ / $2,{ }^{56,57}$ with a line width of $376 \mathrm{G}$ and a resonant field of $3330 \mathrm{G}$ giving a value of $g=2.016$ (Figure S5a). Magnetic measurements of 1 as a function of temperature were performed using a polycrystalline sample in the range of $1.8-300 \mathrm{~K}$ at $1 \mathrm{kOe}$. The temperature dependence of the magnetization is shown in Figure $3 \mathrm{a}$ as $\chi_{\mathrm{m}}$ vs $T$ and $\chi_{\mathrm{m}}{ }^{-1}$ vs $T$ plots. The $\chi_{\mathrm{m}}$ vs $T$ plot shows an increase in the $\chi_{\mathrm{m}}$ value as the temperature is lowered, leading to a maximum of $0.3 \mathrm{emu} \mathrm{mol}{ }^{-1}$ at $50 \mathrm{~K}$. From this temperature, a constant decrease is observed, leading to a non-zero value of $0.2 \mathrm{emu} \mathrm{mol}{ }^{-1}$ at $1.8 \mathrm{~K}$. On the other hand, the $\chi_{\mathrm{m}}{ }^{-1}$ vs $T$ plot gives $C$ and $\theta$ values of $44.6 \mathrm{emu} \mathrm{mol}^{-1}$ and $-73.2 \mathrm{~K}$, respectively. Furthermore, a $35.5 \mathrm{emu} \mathrm{K} \mathrm{mol}^{-1}$ value is obtained at room temperature $\left(4.44 \mathrm{emu} \mathrm{K} \mathrm{mol}^{-1}\right.$ per $\mathrm{Fe}^{\mathrm{III}}$ center) from the $\chi_{\mathrm{m}} T$ vs $T$ plot (Figure S5b), close to the expected for eight non-interacting $\mathrm{Fe}^{\mathrm{III}}$-HS centers, $35.56 \mathrm{emu} \mathrm{K} \mathrm{mol}{ }^{-1}$ considering $S_{\mathrm{Fe}}=5 / 2$ and $g=2.016$. Lowering the temperature, the $\chi_{\mathrm{m}} T$ product constantly decreases as the temperature reaches $100 \mathrm{~K}$. Below this temperature, a more pronounced decrease is observed, reaching a minimum value of $0.3 \mathrm{emu} \mathrm{K} \mathrm{mol}^{-1}$ at $1.8 \mathrm{~K}$. Clearly, the susceptibility data shows that an antiferromagnetic behavior is the predominant phenomenon of the $\mathrm{Fe}_{8}$ III coordination cluster. Field-dependent magnetization measurements were performed at $1.8,3,5$, and $8 \mathrm{~K}$ and represented as $N_{\beta}$ vs $H$ and $N_{\beta}$ vs $H T^{-1}$ plots (Figure S6). The curves $N_{\beta}$ vs $H$ show a lack of saturation at the studied conditions, leading to a maximum near to $4 \mu_{\mathrm{B}}$ at $90 \mathrm{kOe}$, very far than the value expected for eight $\mathrm{Fe}^{\mathrm{III}}$ cations in high spin (40 $\left.\mu_{\mathrm{B}}\right)$. For an antiferromagnetic system with a spin state of $S=0$ at low temperatures, the observed magnetization only can belong from non-zero spin states that are close to the ground state. Then, the absence of saturation and the small values obtained for the magnetization corroborate that antiferromagnetic interactions predominate in the $\mathrm{Fe}_{8}{ }^{\mathrm{III}}$ coordination cluster at low temperatures.

As Figure 3 shows, 12 equivalent $\mu-1 \kappa^{2} N, O: 2 \kappa^{2} N^{\prime}, O^{\prime \prime \prime}$ magnetic pathways can be established (the edges of the cube) between the eight $\mathrm{Fe}^{\mathrm{III}}-\mathrm{HS}$ in the octanuclear molecular structure of $\mathbf{1}$, leading to the following spin Hamiltonian:

$$
\begin{aligned}
\hat{H}_{8}= & -J S_{\mathrm{Fe} 1} S_{\mathrm{Fe} 2}-J S_{\mathrm{Fe} 2} S_{\mathrm{Fe} 3}-J S_{\mathrm{Fe} 3} S_{\mathrm{Fe} 4}-J S_{\mathrm{Fe} 4} S_{\mathrm{Fe} 1} \\
& -J S_{\mathrm{Fe} 5} S_{\mathrm{Fe} 6}-J S_{\mathrm{Fe} 6} S_{\mathrm{Fe} 7}-J S_{\mathrm{Fe} 7} S_{\mathrm{Fe} 8}-J S_{\mathrm{Fe} 5} S_{\mathrm{Fe} 8} \\
& -J S_{\mathrm{Fe} 1} S_{\mathrm{Fe} 5}-J S_{\mathrm{Fe} 2} S_{\mathrm{Fe} 6}-J S_{\mathrm{Fe} 3} S_{\mathrm{Fe} 7}-J S_{\mathrm{Fe} 4} S_{\mathrm{Fe} 8}
\end{aligned}
$$

No analytical model has been developed for such a complex system. For this reason, the use of a simplified model was necessary. Considering the symmetry of the cluster, the cubic system can be simplified to a binuclear system that consists in two $\mathrm{Fe}^{\mathrm{III}}$-HS cations, connected by a single $\mu-1 \kappa^{2} N, O: 2 \kappa^{2} N^{\prime}, \mathrm{O}^{\prime \prime \prime}$ bridge (Figure $3 \mathrm{~b}$ ), leading to the following spin Hamiltonian:

$$
\hat{H}_{2}=-J S_{\mathrm{Fe} 1} S_{\mathrm{Fe} 2}
$$

A fit of the experimental susceptibility data by matrix diagonalization using the $\hat{\mathrm{H}}_{2}$ spin Hamiltonian using the $\mathrm{PHI}^{36}$ software was performed between 300 and $1.8 \mathrm{~K}$, considering $S_{\mathrm{Fe} i}=5 / 2$ and maintaining the $g$ factor fixed to the experimental value obtained by EPR, $g=2.016$ (Figure 4 ). A

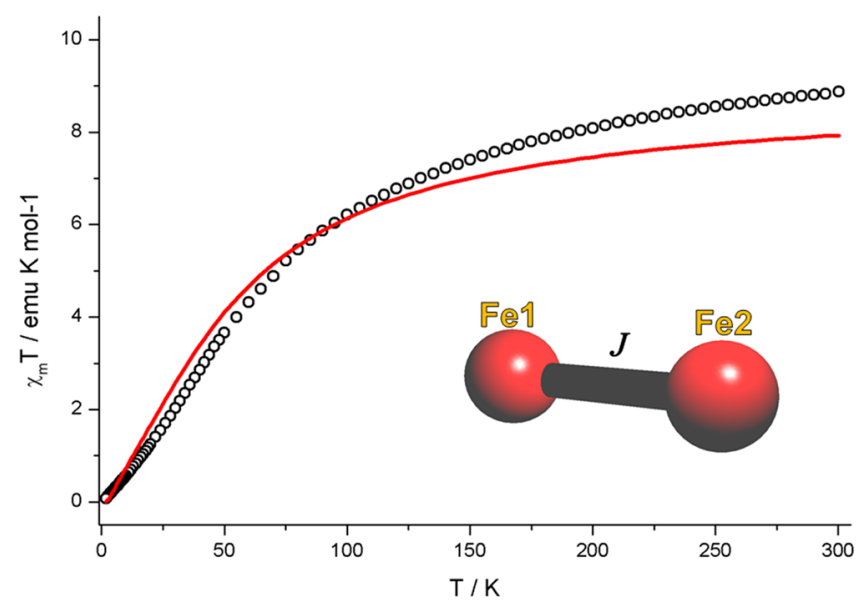

Figure 4. Fitting of $\chi_{\mathrm{m}} T$ vs $T$ at $1 \mathrm{kOe}$ and using a simplified binuclear model.

magnetic coupling constant of $J=-3.8 \mathrm{~cm}^{-1}$ was obtained, with an agreement factor of $R=8.5 \times 10^{-3}\left(R=\Sigma\left(\chi_{\mathrm{m}} T_{\text {obs }}\right)-\right.$ $\left.\left(\chi_{\mathrm{m}} T_{\exp }\right)^{2} / \Sigma\left(\chi_{\mathrm{m}} T_{\text {obs }}\right)^{2}\right)$. The use of a free $g$ value gave a better fit (Figure S5c), obtaining $J$ and $g$ values of $-5.28 \mathrm{~cm}^{-1}$ and 2.178 , respectively. In both cases, the negative sign and a similar magnitude of the magnetic exchange coupling confirm the antiferromagnetic nature of the superexchange interaction of $\mathrm{Fe}^{\mathrm{III}}$-HS cations through $\mu-1 \kappa^{2} N, O: 2 \kappa^{2} N^{\prime}, O^{\prime \prime \prime}$ bridges. However, the use of a $g$ value of 2.016, obtained from EPR measurements, seems to be more adequate and in agreement with the structural features of the $\mathrm{Fe}^{\mathrm{III}}-\mathrm{HS}$ cations. The magnitude and sign of the coupling constants also are in agreement with the antiferromagnetic interactions observed by Angaridis et al. ${ }^{40}$ between $\mathrm{Fe}^{\mathrm{III}}-\mathrm{HS} / \mathrm{Fe}^{\mathrm{III}}-\mathrm{HS}$ mediated by $\mu-1 \kappa^{2} N, O: 2 \kappa^{2} N^{\prime}, O^{\prime \prime \prime}$ bridges with $J=-4.8(2) \mathrm{cm}^{-1}$. The interaction between $\mathrm{Fe}^{\mathrm{III}}-\mathrm{HS} / \mathrm{Fe}^{\mathrm{III}}-\mathrm{HS}$ can be rationalized considering the five magnetic orbitals associated with $\mathrm{Fe}^{\mathrm{III}}$-HS in an octahedral environment (two $\mathrm{e}_{\mathrm{g}}$ and three $t_{2 g}$ ). Thus, the interaction through the IDC $^{3-}$ ligand generates a greater possibility of overlapping between the five orbitals of each $\mathrm{Fe}^{\mathrm{III}}$-HS center. ${ }^{58}$ The fact that the binuclear model presents a rather moderate fit of the magnetic behavior can be explained on the base of the crude simplification of the octanuclear structure of 1 . An analogous $\mathrm{Ni}_{8}{ }^{\mathrm{II}}$ cluster was reported by Liu et al., ${ }^{42}\left(\mathrm{H}_{2} \mathrm{TMDP}\right)_{4}(\mathrm{DMF})_{4}(\mathrm{EtOH})_{4}{ }^{-}$ $\left(\mathrm{H}_{2} \mathrm{O}\right)_{6}\left[\mathrm{Ni}_{8}(\mathrm{HImDC})_{12}\right]$ (DMF $=N, N^{\prime}$-dimethylformamide, $\mathrm{EtOH}=$ ethanol, and $\mathrm{H}_{2} \mathrm{TMDP}=4,4^{\prime}$-trimethylenedipiperidinium), having the same cubic structure of 1 and the same $\mu$ $1 \kappa^{2} N, O: 2 \kappa^{2} N^{\prime}, O^{\prime \prime \prime}$ connectivity between the metal cations. This compound also presents an antiferromagnetic behavior, with an identical $\chi_{\mathrm{m}}$ vs $T$ tendency compared with 1 . Although no exchange coupling values were given for this $\mathrm{Ni}_{8}$ cluster, this example suggests that the bulk magnetic properties of such cubic systems are related not only with the particular magnetic interactions of the metal cations through $\mu-1 \kappa^{2} N, O: 2 \kappa^{2} N^{\prime}, O^{\prime \prime \prime}$ but also with the spin topology arrangement within the whole cluster structure. In any case, more experimental and theoretical analyses should be performed to clarify the magnetic behavior of compound 1, perhaps studying the orbitals involved in each magnetic exchange pathway and the role of the topology of the cluster in the bulk magnetic properties.

3.6. Mössbauer Spectroscopy. The temperature evolution of the Mössbauer spectra of 1 at 295, 77, and $4.2 \mathrm{~K}$ is shown in Figure 5. In the studied temperature range, each spectrum consists of a doublet, corroborating that $\mathrm{Fe}(1)$ and $\mathrm{Fe}(2)$ 


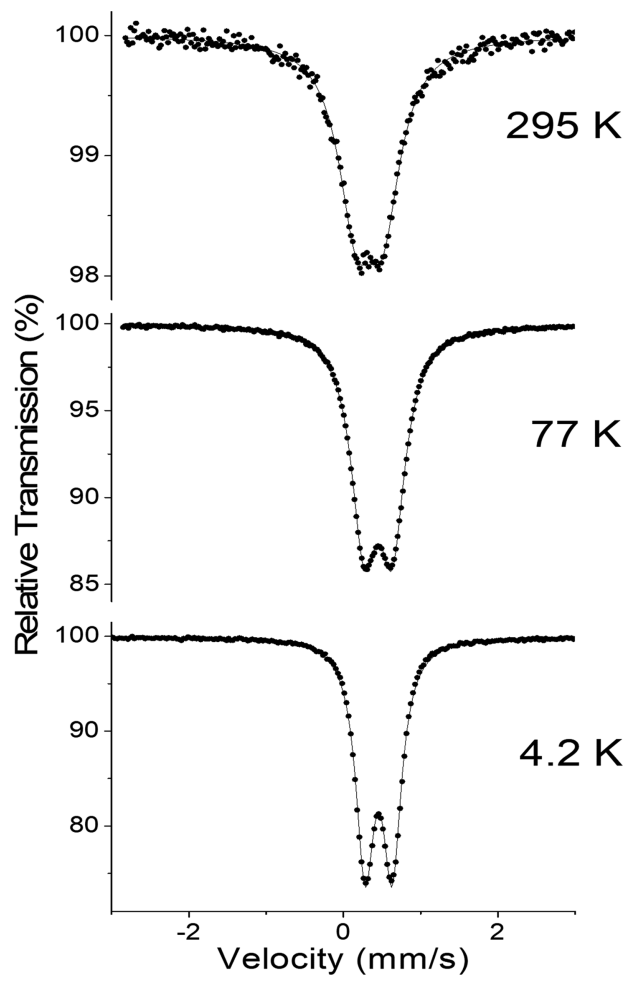

Figure 5. Mössbauer spectra of $\mathbf{1}$ at different temperatures.

present the same coordination environment. Furthermore, the Mössbauer parameters at room temperature, isomer shift $(\delta=$ $\left.0.336(1) \mathrm{mm} \mathrm{s}^{-1}\right)$ and quadrupole splitting $\left(\Delta E_{\mathrm{Q}}=0.369(4)\right.$ $\left.\mathrm{mm} \mathrm{s}^{-1}\right)$, are characteristics of $\mathrm{Fe}^{\mathrm{III}}-\mathrm{HS}$. As the temperature decreases, the isomer shift increases, $\delta=0.447(1) \mathrm{mm} \mathrm{s}^{-1}$ at 4.2 $\mathrm{K}$, according to the second-order Doppler shift; nevertheless, the quadrupole splitting is nearly independent of the temperature $\left(\Delta E_{\mathrm{Q}}=0.352(2) \mathrm{mm} \mathrm{s}^{-1}\right.$ at $\left.4.2 \mathrm{~K}\right)$, as expected for $\mathrm{Fe}^{\mathrm{III}}$ - $\mathrm{HS}$ ions for which the quadrupolar interaction is due only to the lattice contribution. In the same way, the presence of only a doublet even at $4.2 \mathrm{~K}$ would be indicative of the absence of magnetic order or that the relaxation time is shorter than the lifetime of the nuclear excited state. ${ }^{59}$ For the antiferromagnetic $\mathrm{Fe}^{\mathrm{III}}-\mathrm{HS}$ coupled system, a sextet should be observed in the Mössbauer spectrum, below the critical temperature $(50 \mathrm{~K})$. Nevertheless, the spectra recorded at room temperature, $77 \mathrm{~K}$, and $4 \mathrm{~K}$ are almost the same, consisting of a sharp doublet instead of a sextet. This behavior indicates that the relaxation time of compound 1 is shorter than the lifetime of the nuclear excited state (experimental measurement time, $\left.10^{-7} \mathrm{~s}\right) .{ }^{51}$ Such kind of paramagnetic fast spin relaxation has also been reported for other polynuclear $\mathrm{Fe}^{\mathrm{III}}$-HS coupled systems. ${ }^{60,61}$

\section{CONCLUSIONS}

A new iron octanuclear coordination cluster 1 was successfully synthesized under an acid-base reaction using a single ligand, $1 \mathrm{H}$-imidazole-4,5-dicarboxylic acid $\left(\mathrm{H}_{3} \mathrm{IDC}\right)$. The cluster $\left[\mathrm{Fe}_{8}(\mathrm{IDC})_{12}\right]^{12-}$ is formed in basic media and crystallized in acid media, proving the chemical stability of the anionic $\mathrm{Fe}_{8}$ cluster in a wide $\mathrm{pH}$ range. On the other hand, XPS is a very powerful technique that permitted to identify the existence of triethylammonium cations as a charge compensator that balance the charge of the anionic cluster, and to corroborate the chemical identity of the cluster $\left[\mathrm{Fe}_{8}(\mathrm{IDC})_{12}\right]^{12-}$ determined by single-crystal X-ray diffraction. Moreover, it was possible to identify that a reduction process centered on the metal cation is produced under experimental conditions of the XPS technique. In fact, the recorded data have to be carefully analyzed to obtain the correct information on the oxidation state of the metal cation in this type of compound. Additionally, Mössbauer spectroscopy corroborated the spin and oxidation state of the iron center within the cluster, leaving no doubt that only $\mathrm{Fe}^{\mathrm{III}}-\mathrm{HS}$ ions are present in the structure of $\mathbf{1}$. The performed magnetic measurements revealed that weak antiferromagnetic coupling is dominant in the whole temperature range. Although the literature reports the existence of $\mathrm{Mn}^{\mathrm{II}}, \mathrm{Ni}^{\mathrm{II}}, \mathrm{Co}^{\mathrm{II} / \mathrm{III}}, \mathrm{Zn}^{\mathrm{II}}$, and $\mathrm{Cr}^{\mathrm{III}}$-In ${ }^{\mathrm{III}}$ negative or neutral cubic analogous systems forming OD, 1D, or 3D compounds with either $\mathrm{H}_{2} \mathrm{IDC}^{-} / \mathrm{HIDC}^{2-} /$ IDC $^{3-}$ anionic species, compound $\mathbf{1}$ is the first member of this family based on $\mathrm{Fe}^{\mathrm{III}}$. Despite the challenges presented for the characterization of $\mathbf{1}$, the present work collects a complete chemical and physical description of a new $\mathrm{Fe}^{\mathrm{III}}-\mathrm{HS}$ coordination cluster with a novel cubic structure.

\section{ASSOCIATED CONTENT}

\section{Supporting Information}

The Supporting Information is available free of charge at https://pubs.acs.org/doi/10.1021/acsomega.0c02420.

Image of the yellow prismatic crystals of 1 (Figure S1); mass spectra (Figure S2); FTIR spectra (Figure S3); TG in the $\mathrm{N}_{2}$ atmosphere (Figure S4); EPR spectra, $\chi_{\mathrm{m}} T$ vs $T$ plot at $1 \mathrm{kOe}$; best-fit curve at $1 \mathrm{kOe}$ (Figure S5); $N_{\beta}$ vs $H$ and $\mathrm{N}_{\beta}$ vs $H T^{-1}$ plot (Figure S6); complete crystal data and structure (Table S1); peak list of mass spectra (Table S2); and results of CShM calculation (Tables S3-5) (PDF)

Crystal data and structure refinement for $\mathbf{1}$ (CIF)

\section{AUTHOR INFORMATION}

\section{Corresponding Author}

Verónica Paredes-García - Facultad de Ciencias Exactas, Departamento de Ciencias Quimicas, Universidad Andres Bello, 8370146 Santiago, Chile; CEDENNA, 8380494 Santiago, Chile; $\odot$ orcid.org/0000-0002-7537-7430; Phone: +56-226615756; Email: vparedes@unab.cl

\section{Authors}

Carlos Cruz - Facultad de Ciencias Exactas, Departamento de Ciencias Quimicas, Universidad Andres Bello, 8370146 Santiago, Chile; CEDENNA, 8380494 Santiago, Chile

Andrés Igor Vega Carvallo - Facultad de Ciencias Exactas, Departamento de Ciencias Quimicas, Universidad Andres Bello, 8370146 Santiago, Chile; CEDENNA, 8380494 Santiago, Chile; (1) orcid.org/0000-0001-6501-4161

Evgenia Spodine - CEDENNA, 8380494 Santiago, Chile; Facultad de Ciencias Quimicas y Farmacéuticas, Departamento de Quimica Inorgánica y Analitica, Universidad de Chile, 8380492 Santiago, Chile

Albert Escuer - Departament de Quimica Inorgànica, Universitat de Barcelona, 08028 Barcelona, Spain; 이이.org/00000002-6274-6866

José F. Marco - Instituto de Química Física Rocasolano, 28013 Madrid, Spain

Nieves Menéndez - Departamento de Química Física Aplicada, Facultad de Ciencias, Universidad Autonoma de Madrid, 28049 Madrid, Spain 
Diego Venegas-Yazigi - CEDENNA, 8380494 Santiago, Chile; Facultad de Quimica y Biologia, Departamento de Quimica de los Materiales, Universidad de Santiago de Chile, 9170022 Santiago, Chile; () orcid.org/0000-0001-7816-2841

Complete contact information is available at: https://pubs.acs.org/10.1021/acsomega.0c02420

\section{Notes}

The authors declare no competing financial interest. Accession code CCDC 1810846 contains the supplementary crystallographic data for this publication. These data can be obtained free of charge via www.ccdc.cam.ac.uk/data_request/ cif, or by emailing data_request@ccdc.cam.ac.uk, or by contacting The Cambridge Crystallographic Data Centre, 12 Union Road, Cambridge CB2 1EZ, UK; fax: +44 1223336033.

\section{ACKNOWLEDGMENTS}

The authors acknowledge FONDECYT 1170887, Proyecto Anillo CONICYT ACT 1404 grant, CONICYT-FONDEQUIP/PPMS/EQM130086, CONICYT-FONDEQUIP/ EQM140060, Chilean-French International Associated Laboratory for Multifunctional Molecules, and Materials LIAM3CNRS $\mathrm{N}^{\circ} 1027$ for financial support. The authors also acknowledge Financiamiento Basal, AFB180001, CEDENNA and Laboratory of Analyses of Solids (L.A.S-UNAB). JFM acknowledges financial support from the Spanish Agencia Estatal de Investigación (AEI) through Project No. RTI2018095303-B-C51 and the Comunidad de Madrid through Project. NANOMAGCOST-CM P2018/NMT-4321. NM acknowledges Agencia Estatal de Investigación Española PGC2018095642-B-I00 proyect.

\section{REFERENCES}

(1) Cronin, L.; Fielden, J. Coordination Clusters. In Encyclopedia of Supramolecular Chemistry; 1st ed.; Atwood, J. L. Ed.; Taylor and Francis: London, Published online 2007; 1-10, DOI: 10.1081/EESMC-120024346.

(2) Kostakis, G. E.; Powell, A. K. An Approach to Describing the Topology of Polynuclear Clusters. Coord. Chem. Rev. 2009, 253, 26862697.

(3) Sivaramakrishna, A.; Clayton, H. S.; Makhubela, B. C. E.; Moss, J. R. Platinum Based Mixed-Metal Clusters (PtnMm(CO)xLy, $M=R u$ or Os; $\mathrm{n}+\mathrm{m}=2$ to 10 and Ly = Other Ligands)-Synthesis, Structure, Reactivity and Applications. Coord. Chem. Rev. 2008, 252, 1460-1485.

(4) Kostakis, G. E.; Perlepes, S. P.; Blatov, V. A.; Proserpio, D. M.; Powell, A. K. High-Nuclearity Cobalt Coordination Clusters: Synthetic, Topological and Magnetic Aspects. Coord. Chem. Rev. 2012, 256, 1246-1278.

(5) Beltran, L. M. C.; Long, J. R. Directed Assembly of Metal-Cyanide Cluster Magnets. Acc. Chem. Res. 2005, 38, 325-334.

(6) Peng, J.-B.; Zhang, Q.-C.; Kong, X.-J.; Zheng, Y.-Z.; Ren, Y.-P.; Long, L.-S.; Huang, R.-B.; Zheng, L.-S.; Zheng, Z. High-Nuclearity 3d$4 f$ Clusters as Enhanced Magnetic Coolers and Molecular Magnets. J. Am. Chem. Soc. 2012, 134, 3314-3317.

(7) Müller, A.; Peters, F.; Pope, M. T.; Gatteschi, D. Polyoxometalates: Very Large Clusters Nanoscale Magnets. Chem. Rev. 1998, 98, 239-272.

(8) Zhang, S.; Cheng, P. Coordination-Cluster-Based Molecular Magnetic Refrigerants. Chem. Rec. 2016, 16, 2077-2126.

(9) Sessoli, R.; Tsai, H. L.; Schake, A. R.; Wang, S.; Vincent, J. B.; Folting, K.; Gatteschi, D.; Christou, G.; Hendrickson, D. N. High-Spin Molecules: $\left[\mathrm{Mn}_{12} \mathrm{O}_{12}\left(\mathrm{O}_{2} \mathrm{CR}\right)_{16}\left(\mathrm{H}_{2} \mathrm{O}\right)_{4}\right]$. J. Am. Chem. Soc. 1993, 115, $1804-1816$.

(10) Sessoli, R.; Gatteschi, D.; Caneschi, A.; Novak, M. A. Magnetic Bistability in a Metal-Ion Cluster. Nature 1993, 365, 141-143.
(11) McInnes, E. J. L.; Anson, C.; Powell, A. K.; Thomson, A. J.; Poussereau, S.; Sessoli, R. Solvothermal Synthesis of $\left[\mathrm{Cr}_{10}(\mu\right.$ $\left.\mathrm{O}_{2} \mathrm{CMe}\right)_{10}(\mu \text {-OR })_{20}$ ] 'Chromic Wheels' with Antiferromagnetic $(\mathrm{R}=$ $\mathrm{Et})$ and Ferromagnetic $(\mathrm{R}=\mathrm{Me}) \mathrm{Cr}(\mathrm{III}) \cdots \mathrm{Cr}(\mathrm{III})$ Interactions. Chem. Commun. 2001, 10, 89-90.

(12) Liu, J.-L.; Leng, J.-D.; Lin, Z.; Tong, M.-L. Ferromagnetic Homometallic $\mathrm{Mn}_{19}$ Cluster and Heterometallic $\mathrm{Na}_{2} \mathrm{Mn}_{15}$ Cluster with Large Spin State as Magnetic Refrigerants. Chem. - Asian J. 2011, 6, 1007-1010.

(13) Goura, J.; Chandrasekhar, V. Molecular Metal Phosphonates. Chem. Rev. 2015, 115, 6854-6965.

(14) Kitashima, R.; Imatomi, S.; Yamada, M.; Matsumoto, N.; Maeda, Y. Gradual Two-step Spin Crossover Behavior of Binuclear Iron(III) Complex Bridged by trans-1,2-Bis(4-pyridyl)ethylene. Chem. Lett. 2005, 34, 1388-1389.

(15) Sheikh, J. A.; Jena, H. S.; Clearfield, A.; Konar, S. Phosphonate Based High Nuclearity Magnetic Cages. Acc. Chem. Res. 2016, 49, 1093-1103.

(16) Evangelisti, M.; Candini, A.; Ghirri, A.; Affronte, M.; Piligkos, S.; Brechin, E. K.; McInnes, E. J. L. Molecular Nanoclusters as Magnetic Refrigerants: The Case of $\mathrm{Fe}_{14}$ with Very Large Spin Ground-State. Polyhedron 2005, 24, 2573-2578.

(17) McCusker, J. K.; Christmas, C. A.; Hagen, P. M.; Chadha, R. K.; Harvey, D. F.; Hendrickson, D. N. Spin Frustration: A Hexanuclear Ferric Complex with a $S=5$ Ground State. J. Am. Chem. Soc. 1991, 113, 6114-6124.

(18) Weighardt, K.; Pohl, K.; Jibril, I.; Huttner, G. Hydrolysis Products of the Monomeric Amine Complex $\left(\mathrm{C}_{6} \mathrm{H}_{15} \mathrm{~N}_{3}\right) \mathrm{FeCl}_{3}$ : The Structure of the Octameric Iron(III) Cation of $\left\{\left[\left(\mathrm{C}_{6} \mathrm{H}_{15} \mathrm{~N}_{3}\right)_{6} \mathrm{Fe}_{8}\left(\mu_{3}\right.\right.\right.$ $\left.\left.\mathrm{O})_{2}\left(\mu_{2}-\mathrm{OH}\right)_{12}\right] \mathrm{Br}_{7}\left(\mathrm{H}_{2} \mathrm{O}\right)\right\} \mathrm{Br} \cdot 8 \mathrm{H}_{2} \mathrm{O}$. Angew. Chem., Int. Ed. Engl. 1984, $23,77-78$.

(19) Konar, S.; Clearfield, A. Synthesis and Characterization of High Nuclearity Iron(III) Phosphonate Molecular Clusters. Inorg. Chem. 2008, 47, 5573-5579.

(20) Kang, S.; Zheng, H.; Liu, T.; Hamachi, K.; Kanegawa, S.; Sugimoto, K.; Shiota, Y.; Hayami, S.; Mito, M.; Nakamura, T.; Nakano, M.; Baker, M. L.; Nojiri, H.; Yoshizawa, K.; Duan, C.; Sato, O. A Ferromagnetically Coupled $\mathrm{Fe}_{42}$ Cyanide-Bridged Nanocage. Nat. Commun. 2015, 6, 5955.

(21) Winpenny, R. E. P. High Nuclearity Clusters: Clusters and Aggregates with Paramagnetic Centers: Oxygen and Nitrogen Bridged Systems. In Comprehensive Coordination Chemsitry II: From the biology to nantechnology; 2nd ed.; McCleverty, J. A.; Meyer, T. J., Ed; Elsevier: Oxford, 2004, 126-174.

(22) Berdiell, I. C.; Hochdörffer, T.; Desplanches, C.; Kulmaczewski, R.; Shahid, N.; Wolny, J. A.; Warriner, S. L.; Cespedes, O.; Schünemann, V.; Chastanet, G.; Halcrow, M. A. Supramolecular Iron Metallocubanes Exhibiting Site-Selective Thermal and Light-Induced Spin-Crossover. J. Am. Chem. Soc. 2019, 141, 18759-18770.

(23) Struch, N.; Bannwarth, C.; Ronson, T. K.; Lorenz, Y.; Mienert, B.; Wagner, N.; Engeser, M.; Bill, E.; Puttreddy, R.; Rissanen, K.; Beck, J.; Grimme, S.; Nitschke, J. R.; Lützen, A. An Octanuclear Metallosupramolecular Cage Designed To Exhibit Spin-Crossover Behavior. Angew. Chem., Int. Ed. 2017, 56, 4930-4935.

(24) Strohalm, M.; Hassman, M.; Košata, B.; Kodíček, M. MMass Data Miner: An Open Source Alternative for Mass Spectrometric Data Analysis. Rapid Commun. Mass Spectrom. 2008, 22, 905-908.

(25) Strohalm, M.; Kavan, D.; Novák, P.; Volný, M.; Havlícek, V. MMass 3: A Cross-Platform Software Environment for Precise Analysis of Mass Spectrometric Data. Anal. Chem. 2010, 82, 4648-4651.

(26) Niedermeyer, T. H. J.; Strohalm, M. MMass as a Software Tool for the Annotation of Cyclic Peptide Tandem Mass Spectra. PLoS One 2012, 7, e44913-e44913.

(27) SAINT V6.22; Bruker AXS Inc.: Madison, WI, USA, 2000.

(28) SADABS V2.05; Bruker AXS Inc.: Madison, WI, USA, 2001.

(29) Sheldrick, G. M. SHELXT - Integrated Space-Group and CrystalStructure Determination. Acta Crystallogr., Sect. A: Found. Adv. 2015, $71,3-8$. 
(30) Sheldrick, G. M. Crystal Structure Refinement with SHELXL. Acta Crystallogr., Sect. C: Struct. Chem. 2015, 71, 3-8.

(31) Blatov, V.; Shevchenko, A. ToposPro, Program Package for Multipurpose Crystallochemical Analysis. In ToposPro V5.0, program package for multipurpose crystallochemical analysis; 2014.

(32) Van Der Sluis, P. V.; Spek, A. L. BYPASS: An Effective Method for the Refinement of Crystal Structures Containing Disordered Solvent Regions. Acta Crystallogr., Sect. A: Found. Crystallogr. 1990, 46, 194-201.

(33) Spek, A. L. PLATON SQUEEZE: A Tool for the Calculation of the Disordered Solvent Contribution to the Calculated Structure Factors. Acta Crystallogr. Sect. C Struct. Chem. 2015, 71, 9-18.

(34) Brand, R. A. Improving the Validity of Hyperfine Field Distributions from Magnetic Alloys: Part I: Unpolarized source. Nucl. Instrum. Methods Phys. Res., Sect. B 1987, 28, 398-416.

(35) Bain, G. A.; Berry, J. F. Diamagnetic Corrections and Pascal's Constants. J. Chem. Educ. 2008, 85, 532-536.

(36) Chilton, N. F.; Anderson, R. P.; Turner, L. D.; Soncini, A.; Murray, K. S. PHI : A Powerful New Program for the Analysis of Anisotropic Monomeric and Exchange-Coupled Polynuclear $d$ - and $f$ Block Complexes. J. Comput. Chem. 2013, 34, 1164-1175.

(37) Steckel, A.; Schlosser, G. An Organic Chemist's Guide to Electrospray Mass Spectrometric Structure Elucidation. Molecules 2019, 24, 611.

(38) McIndoe, J. S.; Vikse, K. L. Assigning the ESI Mass Spectra of Organometallic and Coordination Compounds. J. Mass Spectrom. 2019, 54, 466-479.

(39) Llunell, M.; Casanova, D.; Cirera, J.; Alemany, P.; Alvarez, S. SHAPE V2.1. SHAPE V2.1, Departament de Química Física, Departament de Química Inorgènica, and Institut de Química Teòrica i Computacional, Universitat de Barcelona: Barcelona, España, 2013.

(40) Angaridis, P.; Kampf, J. W.; Pecoraro, V. L. Multinuclear Fe(III) Complexes with Polydentate Ligands of the Family of Dicarboxyimidazoles: Nuclearity- and Topology-Controlled Syntheses and Magneto-Structural Correlations. Inorg. Chem. 2005, 44, 3626-3635.

(41) Sunatsuki, Y.; Ohta, H.; Kojima, M.; Ikuta, Y.; Goto, Y.; Matsumoto, N.; Iijima, S.; Akashi, H.; Kaizaki, S.; Dahan, F.; Tuchagues, J.-P. Supramolecular Spin-Crossover Iron Complexes Based on Imidazole-Imidazolate Hydrogen Bonds. Inorg. Chem. 2004, 43, 4154-4171.

(42) Liu, Y.; Kravtsov, V.; Walsh, R. D.; Poddar, P.; Srikanth, H.; Eddaoudi, M. Directed Assembly of Metal-Organic Cubes from Deliberately Predesigned Molecular Building Blocks. Chem. Commun. 2004, 299, 2806-2807.

(43) Xu, Q.; Zou, R.-Q.; Zhong, R.-Q.; Kachi-Terajima, C.; Takamizawa, S. Cubic Metal-Organic Polyhedrons of Nickel(II) Imidazoledicarboxylate Depositing Protons or Alkali Metal Ions. Cryst. Growth Des. 2008, 8, 2458-2463.

(44) Cheng, A.-L.; Liu, N.; Zhang, J.-Y.; Gao, E.-Q. Assembling the Cage-Based Metal-Organic Network from a Cubic Metalloligand. Inorg. Chem. 2007, 46, 1034-1035.

(45) Zou, R.-Q.; Sakurai, H.; Xu, Q. Preparation, Adsorption Properties, and Catalytic Activity of 3D Porous Metal-Organic Frameworks Composed of Cubic Building Blocks and Alkali-Metal Ions. Angew. Chem., Int. Ed. 2006, 45, 2542-2546.

(46) Alkordi, M. H.; Brant, J. A.; Wojtas, L.; Kravtsov, V. C.; Cairns, A. J.; Eddaoudi, M. Zeolite-like Metal- Organic Frameworks (ZMOFs) Based on the Directed Assembly of Finite Metal- Organic Cubes (MOCs). J. Am. Chem. Soc. 2009, 131, 17753-17755.

(47) Zhai, Q.-G.; Mao, C.; Zhao, X.; Lin, Q.; Bu, F.; Chen, X.; Bu, X.; Feng, P. Cooperative Crystallization of Heterometallic IndiumChromium Metal-Organic Polyhedra and Their Fast Proton Conductivity. Angew. Chem., Int. Ed. 2015, 54, 7886-7890.

(48) Yamashita, T.; Hayes, P. Analysis of XPS Spectra of $\mathrm{Fe}^{2+}$ and $\mathrm{Fe}^{3+}$ Ions in Oxide Materials. Appl. Surf. Sci. 2008, 254, 2441-2449.

(49) Monti, M.; Santos, B.; Mascaraque, A.; de la Fuente, O. R.; Niño, M. A.; Menteş, T. O.; Locatelli, A.; McCarty, K. F.; Marco, J. F.; de la Figuera, J. Oxidation Pathways in Bicomponent Ultrathin Iron Oxide Films. J. Phys. Chem. C 2012, 116, 11539.
(50) Carrasco, E.; Oujja, M.; Sanz, M.; Marco, J. F.; Castillejo, M. XRay and Ion Irradiation Effects on Azurite, Malachite and Alizarin Pictorial Models. Microchem. J. 2018, 137, 381-391.

(51) Silva, K.; Marco, J. F.; Yañez, C. Covalent Immobilization of Amino- $\beta$-cyclodextrins on Glassy Carbon Electrode in Aqueous Media. J. Electrochem. Soc. 2019, 166, G75-G81.

(52) Haque, M. A.; Paliwal, L. J. Synthesis, Spectral Characterization and Thermal Aspects of Coordination Polymers of Some Transition Metal Ions with Adipoyl Bis(Isonicotinoylhydrazone). J. Mol. Struct. 2017, 1134, 278-291.

(53) Peng, H.; Chen, Z.; Tong, L.; Yu, X.; Ran, C.; Liu, Z. Thermochemical Hole Burning on a Triethylammonium Bis-7,7,8,8Tetracyanoquinodimethane Charge-Transfer Complex Using SingleWalled Carbon Nanotube Scanning Tunneling Microscopy Tips. J. Phys. Chem. B 2005, 109, 3526-3530.

(54) Shi, S.-Y.; Chen, L.-Y.; Li, Y.; He, L.-H.; Zhang, J.; Cui, X.-B. Three New Hybrid Compounds Constructed from $\left\{\mathrm{PSb}_{2} \mathrm{Mo}_{12} \mathrm{O}_{40}\right\}$ Polyoxoanions, TMMC or Organic Amines. Inorg. Chem. Commun. 2019, 99, 149-155.

(55) Guseva, G. B.; Ksenofontov, A. A.; Antina, E. V.; Barannikov, V. P.; Vyugin, A. I. Crystal Solvates of Zinc ${ }^{\text {(II) }}$ Bis(Dipyrrinates) with Triethylamine: Composition, Stability and Spectral-Luminescent Properties. J. Coord. Chem. 2016, 69, 901-914.

(56) Sundaresan, S.; Kühne, I. A.; Kelly, C. T.; Barker, A.; Salley, D.; Müller-bunz, H.; Powell, A. K.; Morgan, G. G. Anion Influence on Spin State in Two Novel Fe(III) Compounds: $\left[\mathrm{Fe}\left(5 \mathrm{~F}-\mathrm{Sal}_{2} 333\right)\right]$ X. Crystals 2019, 9, 19.

(57) Nihei, M.; Shiga, T.; Maeda, Y.; Oshio, H. Spin Crossover Iron(III) Complexes. Coord. Chem. Rev. 2007, 251, 2606-2621.

(58) Lescouëzec, R.; Vaissermann, J.; Lloret, F.; Julve, M.; Verdaguer, M. Ferromagnetic Coupling between Low- and High-Spin Iron(III) Ions in the Tetranuclear Complex fac- $\left\{\left[\mathrm{Fe}^{\mathrm{IIII}}\left\{\mathrm{HB}(\mathrm{Pz})_{3}\right\}(\mathrm{CN})_{2}(\mu-\right.\right.$ $\left.\mathrm{CN})]_{3} \mathrm{Fe}^{\mathrm{III}}\left(\mathrm{H}_{2} \mathrm{O}\right)_{3}\right\} \cdot 6 \mathrm{H}_{2} \mathrm{O} \quad\left(\left[\mathrm{HB}(\mathrm{Pz})_{3}\right]^{-}=\operatorname{Hydrotris}(1-\mathrm{Pyrazolyl})-\right.$ Borate). Inorg. Chem. 2002, 41, 5943-5945.

(59) Hoy, G. R. Relaxation Phenomena for Chemists. In Mössbauer Spectroscopy Applied to Inorganic Chemistry; Long, G. J. Ed.; Springer: Boston, MA, 1984; pp 195-226, DOI: 10.1007/978-1-4899-046218.

(60) Goura, J.; Bag, P.; Mereacre, V.; Powell, A. K.; Chandrasekhar, V. Molecular Iron(III) Phosphonates: Synthesis, Structure, Magnetism, and Mössbauer Studies. Inorg. Chem. 2014, 53, 8147-8154.

(61) Prodius, D.; Mereacre, V.; Singh, P.; Lan, Y.; Mameri, S.; Johnson, D. D.; Wernsdorfer, W.; Anson, C. E.; Powell, A. K. Influence of Lanthanides on Spin-Relaxation and Spin-Structure in a Family of $\mathrm{Fe}_{7} \mathrm{Ln}_{4}$ Single Molecule Magnets. J. Mater. Chem. C 2018, 6, 28622872. 